\title{
Watershed Suspended Sediment Supply and Potential Impacts of Dam Removals for an Estuary
}

\author{
David K. Ralston ${ }^{1}$ (D) Brian Yellen ${ }^{2} \cdot$ Jonathan D. Woodruff ${ }^{2}$ \\ Received: 13 March 2020 / Revised: 11 November 2020 / Accepted: 16 November 2020 / Published online: 4 January 2021 \\ (C) The Author(s) 2021
}

\begin{abstract}
Observations and modeling are used to assess potential impacts of sediment releases due to dam removals on the Hudson River estuary. Watershed sediment loads are calculated based on sediment-discharge rating curves for gauges covering $80 \%$ of the watershed area. The annual average sediment load to the estuary is $1.2 \mathrm{Mt}$, of which about $0.6 \mathrm{Mt}$ comes from side tributaries. Sediment yield varies inversely with watershed area, with regional trends that are consistent with substrate erodibility. Geophysical and sedimentological surveys in seven subwatersheds of the Lower Hudson were conducted to estimate the mass and composition of sediment trapped behind dams. Impoundments were classified as (1) active sediment traps, (2) run-of-river sites not actively trapping sediment, and (3) dammed natural lakes and spring-fed ponds. Based on this categorization and impoundment attributes from a dam inventory database, the total mass of impounded sediment in the Lower Hudson watershed is estimated as $4.9 \pm 1.9 \mathrm{Mt}$. This represents about 4 years of annual watershed supply, which is small compared with some individual dam removals and is not practically available given current dam removal rates. More than half of dams impound drainage areas less than $1 \mathrm{~km}^{2}$, and play little role in downstream sediment supply. In modeling of a simulated dam removal, suspended sediment in the estuary increases modestly near the source during discharge events, but otherwise effects on suspended sediment are minimal. Fine-grained sediment deposits broadly along the estuary and coarser sediment deposits near the source, with transport distance inversely related to settling velocity.
\end{abstract}

Keywords Dam removal $\cdot$ Suspended sediment $\cdot$ Watershed sediment yield $\cdot$ Sediment supply $\cdot$ Sediment trapping

\section{Introduction}

Dam removal is occurring at an accelerating pace around the USA, motivated by goals including improving aquatic connectivity, mitigating safety risks, and/or removing structures that no longer serve their intended purpose (O'Connor et al. 2015). Prior to dam removal, impounded sediment can be excavated and taken away, but this approach is often prohibitively expensive or impractical (Randle et al. 2015). Instead, sediment is typically allowed to erode and be transported downstream (Pizzuto 2002). An important consideration in

David K. Ralston and Brian Yellen contributed equally to this work.

Communicated by Dennis Swaney

David K. Ralston

dralston@whoi.edu

1 Woods Hole Oceanographic Institution, Woods Hole, MA, USA

2 University of Massachusetts, Amherst, MA, USA dam removal is the potential environmental impacts of releasing accumulated sediment on downstream habitat (Foley et al. 2017; Grant and Lewis 2015), particularly if the sediment is contaminated (Ashley et al. 2006). Most dam removals are small (e.g., dam height $<10 \mathrm{~m}$, impounded sediment volume $<10,000 \mathrm{~m}^{3}$ ), so the environmental impacts downstream from a single removal are relatively modest (Sawaske and Freyberg 2012; Tullos et al. 2016). However, the compounding impacts of removing a large number of small dams in close succession is unclear, as well how this might compare to the removal of a larger dam where associated downstream impacts can be extensive (Foley et al. 2017; Warrick et al. 2015).

From a geomorphic perspective, dams and their subsequent removal each represent perturbations to Lane's Balance, which describe connections between changes in sediment load $\left(Q_{s}\right)$, grain size $(D)$, river discharge $\left(Q_{r}\right)$, slope $(S)$, and aggradation/degradation rates of the bed (Lane 1955). Dam construction tends to trap sediment, thereby causing a reduction in $Q_{S}$, which if not offset by a reduction in $Q_{r}$ results in streambed degradation until $D$ and $S$ increased enough to adjust to a new steady state. Conversely, dam removal increases 
downstream sediment supply leading to streambed aggradation and a reduction in $D$ and $S$. Several studies have evaluated the aggregate impacts of dams on sediment trapping at regional scales. Renwick et al. (2005) used detailed assessments from sixteen 7.5 USGS quadrangle maps $\left(\sim 150 \mathrm{~km}^{2}\right)$ to estimate that small impoundments capture $21 \%$ of the total drainage area of the conterminous US. This study did not evaluate the Northeast US in detail, but it draws attention to the capacity for small dams to trap substantial amounts of sediment. Observations from river gauge stations confirm declining sediment supply with many large rivers draining to the US East Coast experiencing declines in suspended sediment concentration, potentially associated with dam construction (Weston 2014) in addition to factors such as land use changes and climate-driven discharge trends. However, impacts of reduced sediment supply from damming are not necessarily observed in coastal regions, with many estuarine depocenters continuing to accumulate sediment at rates in excess of sea level rise (Rodriguez et al. 2020). The increasing interest in dam removals raises questions about potential impacts of the release of impounded sediment at watershed and estuary scales.

If storage of fine-grained sediment behind a dam is appreciable (Collins et al. 2020), erosion of the impounded sediment after dam removal can increase suspended sediment concentration (SSC) in the waterway downstream. The resulting increase in turbidity and reduction in water clarity can be similar in magnitude to that induced by large discharge events (Tullos et al. 2016). Studies have found that SSC downstream of dam removals increases with discharge (Ahearn and Dahlgren 2005; Doyle et al. 2003; Major et al. 2012; Riggsbee et al. 2007; Wilcox et al. 2014). The increase in SSC immediately following dam removal and near the impoundment can be a factor of 10 or more greater than initial conditions prior to removal, but SSC decreases after an initial adjustment period (Doyle et al. 2003; Wilcox et al. 2014). For example, sediment concentrations during discharge events several months after a dam removal from the Little River in North Carolina were 1.2-1.8 times greater than before the removal, and only within $10 \mathrm{~km}$ downstream (Riggsbee et al. 2007). A prolonged period of elevated turbidity is unlikely unless an impoundment is storing many times the annual watershed load and has mostly fine-grained sediment (Tullos et al. 2016).

Increases in turbidity following a dam removal depend in part on the fraction of fine sediment in the impoundment, as coarser sediments like sand and gravel are less likely to be transported in suspension (Wilcox et al. 2014). Finer sediment grain sizes (clay, silt, fine sand) typically move farther downstream than coarse sand and gravel, and the coarser fraction typically deposits within a few $\mathrm{km}$ downstream of the dam (Magilligan et al. 2016; Magirl et al. 2015; Major et al. 2012; Wilcox et al. 2014). The downstream distance of coarse sediment deposition has been found to be predictable using the ratio of the impounded sediment volume to the annual watershed sediment input, but this ratio has not been observed to correlate with deposition of finer sediment (Grant and Lewis 2015). Instead, finer material tends to be conveyed more directly through the fluvial system to coastal region (Major et al. 2017).

The fraction of sediment eroded from impoundments after dam removals varies widely, from less than $10 \%$ to more than 90\% (Foley et al. 2017; Major et al. 2017; Tullos et al. 2016). The percentage of sediment eroded has been found to depend more on the characteristics of impounded sediment (i.e., grain size and cohesiveness) and dam deconstruction method (phased vs. rapid breaching) than on discharge conditions following dam removal (Collins et al. 2017; Foley et al. 2017; Grant and Lewis 2015; Magilligan et al. 2016). Generally, coarse sediment (predominantly sand and gravel) is eroded more completely than fine sediment, which can become resistant to mobilization due to consolidation after dewatering (Foley et al. 2017; Major et al. 2017). The dam removal process is important, in that phased dam removals have less sediment erosion than rapid breaching (Foley et al. 2017; Grant and Lewis 2015; Tullos et al. 2016). For example, a dam removal with rapid breaching and no pre-removal dewatering resulted in mobilization of over half of the impounded fine-grained sediment in a brief period (Wilcox et al. 2014).

Much of the research on dam removal has focused on fluvial geomorphology and ecology impacts (Bellmore et al. 2017; Foley et al. 2017; Tullos et al. 2016), and few studies have examined impacts on coastal or estuarine waters farther downstream, where the sediment-water proportionality represented by Lane's Balance has less relevance. Studies of two major dam removals on tributaries of the tidal Columbia River noted that a large fraction of the fine sediment passed through the fluvial network and into the estuary (Major et al. 2012; Wilcox et al. 2014). One of the largest dam removals to date was on the Elwha River (WA), and it included monitoring of discharges into the coastal ocean (Warrick et al. 2015). The Elwha project involved phased removals of two dams, exposing $30 \mathrm{Mt}$ of impounded sediment. After 5 years of monitoring, an estimated $65 \%$ of the impounded sediment had been eroded, and $90 \%$ of that eroded material was delivered to the coastal zone where it deposited in the delta or dispersed outside the study area (Ritchie et al. 2018). Deposition rates in the submarine delta were about 100 times greater than before removal, and were strongly grain-size dependent, with most of the sand and gravel depositing within $2 \mathrm{~km}$ of the mouth compared to just $6 \%$ of the mud (Gelfenbaum et al. 2015). In the fluvial channel, sediment transport was 3 and 20 times the average annual load in years 1 and 2 after removal respectively, despite lower-than-normal discharge conditions (Magirl et al. 2015; Ritchie et al. 2018). 
Increased sediment concentrations and deposition rates from dam removals can have adverse ecosystem impacts. High deposition rates near the mouth of the Elwha were linked to reductions in macroalgae and changes in the abundance of invertebrate and fish taxa (Rubin et al. 2017), and were associated with decreased light availability (Glover et al. 2019). However, increased sediment inputs can also be beneficial to a coastline, particularly in regions with limited sediment supply, where sediment from dam removals can help mitigate shoreline erosion and promote marsh resilience (Ganju 2019; Ganju et al. 2013). For the Elwha, the shoreline near the river mouth was erosional prior to dam removal, but increased sediment supply reversed this trend and led to coastal accretion (Warrick et al. 2019). The timescales for adjustment in the coastal zone to changes in sediment supply can be long. For example, sediment loading to San Francisco Bay increased substantially with hydraulic mining in the late 1800 s and then decreased with the building of large dams in the middle of the twentieth century, but the turbidity response in the estuary lagged as the mobile pool of sediment available for resuspension adjusted over time scales of decades (Schoellhamer 2011). Similarly, the ecosystem response lagged changes in sediment supply by decades, including changes in phytoplankton, fish, and submerged vegetation with water clarity (Schoellhamer et al. 2013).

As interest in dam removals grows, especially in the Northeast US, there is a need to examine potential impacts on estuaries and coastal regions downstream. Regulators and dam removal practitioners want to assess sediment release impacts and develop mitigation strategies. Environmental managers want to minimize harmful outcomes due to increased turbidity or deposition, but also assess if increased sediment loading may aid in resilience of coastal wetlands to sea level rise. The cumulative sediment release from many small dam removals in a watershed may have considerable impacts in the estuary downstream, and maps highlighting the widespread distribution of dams in watersheds like the Hudson (black dots in Fig. 1a) are often shown as qualitative evidence for significant reduction in sediment delivery to estuaries and coastlines. Here, we provide one of the first quantitative assessments on the potential impacts of dam removals to estuaries in Northeastern US. The study is focused to the Hudson River estuary as a representative system that has many dams of varying size and a growing regional interest in dam removal. The aims of this research are (1) to quantify the background annual sediment loading to the estuary for comparison with the mass of impounded sediment, (2) to estimate the total amount of sediment trapped in impoundments in the watershed, and (3) simulate potential effects of a representative dam removal on suspended sediment conditions in the estuary. The study focuses on the Hudson, but has broader relevance that should improve assessments of dam removal impacts on other estuaries, particularly for regions like the
Northeastern US where sediment yield is relatively low (Meade 1969) and the number of small dams per area is high (Graf 1999).

\section{Methods}

\section{Site Description}

Tides extend $240 \mathrm{~km}$ up the Hudson River from The Battery in New York City until just below the confluence of the Mohawk and Upper Hudson Rivers in Troy, NY (Fig. 1). The limit of salinity intrusion (i.e., the oligohaline-to-fresh transition) varies seasonally with river discharge, from around Piermont (river km 40) during high flow to near Poughkeepsie (rkm 120) during extreme low discharge (Bowen and Geyer 2003; Ralston et al. 2008). The Mohawk and Upper Hudson combine for a mean annual discharge of about $420 \mathrm{~m}^{3} \mathrm{~s}^{-1}$. Smaller tributaries flowing directly into the tidal Hudson increase this by $30-60 \%$ (Lerczak et al. 2006; Wall et al. 2008). Mean tidal range is about $1.4 \mathrm{~m}$ at The Battery, decreasing to 1 $\mathrm{m}$ around West Point (rkm 90) and increasing to $1.6 \mathrm{~m}$ at the tidal limit at Troy, NY (Ralston et al. 2019). For purposes of clarity and consistency with previous work (Hoitink and Jay 2016; Ralston and Geyer 2017), here we refer to the entire tidal reach of the Lower Hudson as the "estuary," and specify the fresh tidal river and saline estuary regions as appropriate.

Bed sediment in the upper $60 \mathrm{~km}$ of the fresh tidal river is predominately sand, and the bed is muddier in the middle and lower estuary (Nitsche et al. 2007). Suspended sediment concentrations (SSC) in the estuary increase during high river discharge and spring tides. In the fresh tidal river, SSC can be several hundred $\mathrm{mg} / \mathrm{L}$ during high discharge events and decrease by a factor of 10 during lower discharge periods, and SSC can vary by a factor of 2 or more with the springneap tidal cycle (Ralston and Geyer 2017; Wall et al. 2008). In the saline estuary, estuarine turbidity maxima (ETM) have SSC of several hundred to $1000 \mathrm{mg} / \mathrm{L}$ (Geyer et al. 2001; Ralston et al. 2012).

This study focuses on three regions near tidal marshes that are part of the Hudson River National Estuarine Research Reserve (HRNERR) and their associated side tributary watersheds (Fig. 1), and include (1) Stockport Creek watershed that discharges into the tidal Hudson near Stockport Flats marsh (rkm 193); (2) Esopus, Saw Kill, and Stony Creek watersheds that discharge near Tivoli Bays marshes (rkm 158); and (3) Doodletown Brook, Peekskill Hollow Creek, and Popolopen Creek watersheds that discharge near Iona Island marsh (rkm 72). Stockport Creek is formed by the junction of two tributaries, Kinderhook and Claverack Creeks, only $2 \mathrm{~km}$ upstream from its mouth. The seven watersheds were selected to represent a range of catchment conditions, and the three separate discharge locations along the estuary. The upper two 


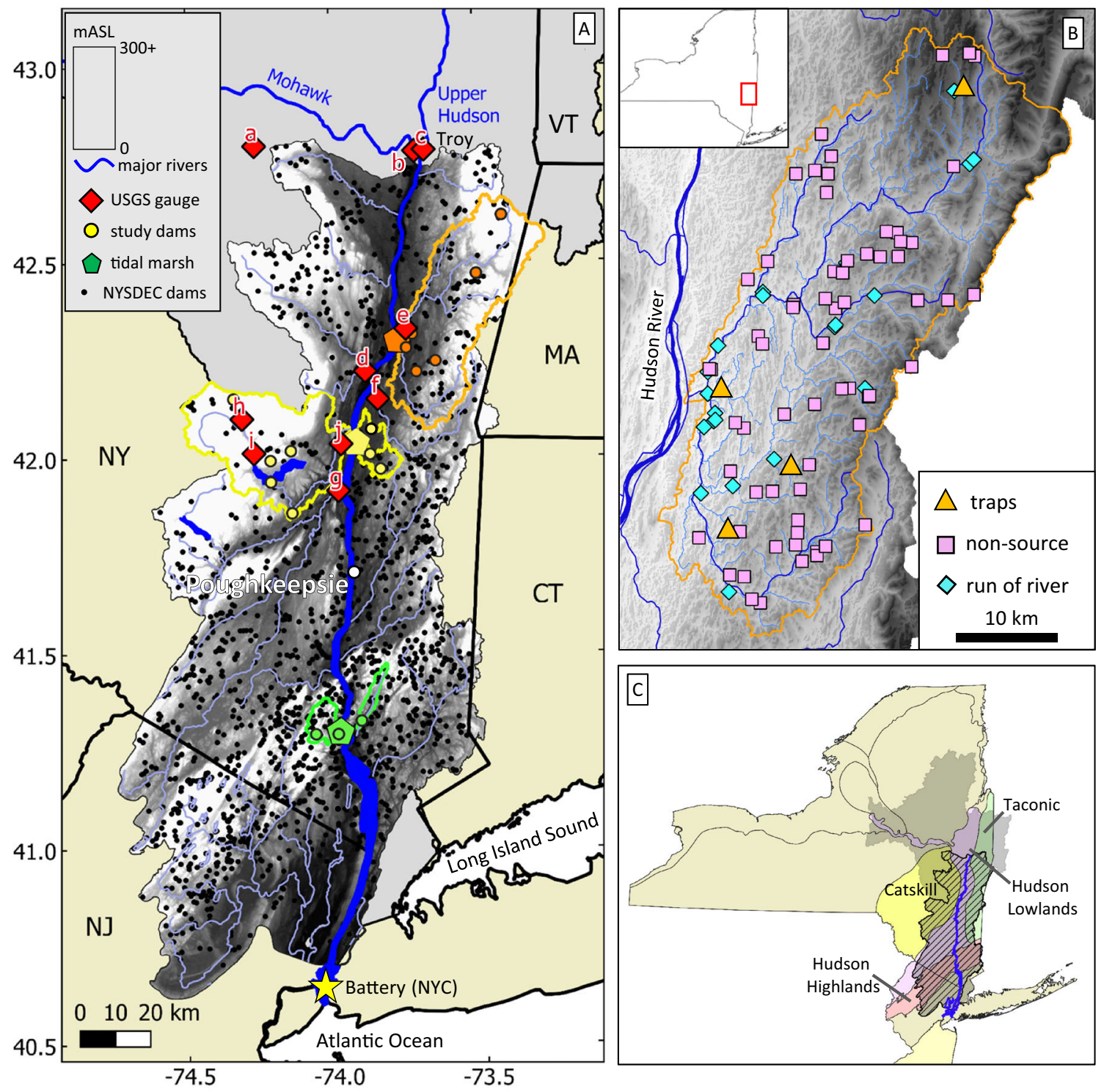

Fig. 1 a Elevation in the Lower Hudson River watershed (grayscale) with Upper Hudson and Mohawk River watersheds in solid gray across the US states of New York (NY), Massachusetts (MA), Connecticut (CT), and New Jersey (NJ). USGS gauges (red diamonds) are labeled with letters corresponding to Table 1 and Fig. 3. Watersheds in which dams were studied in detail are outlined in orange (Stockport), yellow (Esopus; Stoney Creek; Saw Kill), and green (Doodletown-Popolopen; Canopus
Creek), and study impoundments are marked. Black dots show all NYSDEC dams. b Stockport Creek watershed with NYSDEC dams classified by category: 1 . active sediment traps, 2 . run-of-river sites, and 3 . non-sources of sediment. See the "Methods" section for classification criteria. c Physiographic provinces of New York State and New Jersey with the Lower Hudson watershed (hashed area) provinces labeled. The broader Hudson River basin is shaded gray discharge locations are in the fresh tidal river, whereas at Iona Island, the estuary is fresh during moderate-to-high discharge conditions and brackish at low discharge. Impoundment study sites within the seven separate watersheds include steep and low gradient streams, deforestation from less than $1 \%$ to $52 \%$, and catchment areas of 0.4 to $440 \mathrm{~km}^{2}$.

Geology, relief, and land use vary considerably across the Lower Hudson watershed, and four main physiographic provinces have been identified in the region (Fig. 1c). To the south, the Hudson Highlands are characterized by crystalline, highgrade metamorphic bedrock (Dicken et al. 2005), with generally thin sandy soils (Olsson 1981). The Taconic province makes up much of the eastern Lower Hudson watershed, and is characterized by low-grade metamorphic rocks from the Taconic Orogeny (Faber 2002), with more resistant layers forming ridges. The Hudson Lowlands are dominated by extensive lacustrine silts and clays, with highly variable underlying material derived from tilted slices of marine sedimentary rocks and low-grade metamorphic rocks from the Taconic Orogeny (Faber 2002). The Lowlands region is more agricultural than the other provinces due to its flat terrain. West of the Hudson, clastic sedimentary rocks make up most of the 
Catskill Mountains physiographic province (Dicken et al. 2005), with limited exposures of glaciolacustrine clays contributing substantial sediment to upland streams (McHale and Siemion 2014). Due to its mountainous terrain and protected municipal watershed lands, this region is less than $4 \%$ deforested. Above the limit of tidal influence, the Mohawk River watershed to the west has predominantly fine-grained clastic sedimentary bedrock and extensive agriculture in its broad valley that spans the high sediment yield Allegheny Plateau and Mohawk Lowlands Provinces (Nagle et al. 2007). In contrast, the Upper Hudson River watershed to the east is more forested and underlain by crystalline metamorphic rock (Phillips and Hanchar 1996).

\section{Geophysical Measurements}

We selected impoundment study sites from the watersheds adjacent to the NERRS tidal marshes, starting with the New York State Inventory of Dams (New York State Department of Environmental Conservation (NYSDEC) 2019) (Fig. 1a). This database includes most dams built since 1900 and all dams with a hazard classification of high or intermediate (A. Dominitz, personal communication, June 26, 2020). Some small or naturally breached dams are not included in this database, but it is difficult to estimate the number of omitted dams. Field inspection of several omitted dams that we were able to identify from aerial photos revealed cobble or bedrock channels with no fine sediment trapping due to their small size and negligible accommodation space. Impoundment attributes from the database include dam height, dam width, average water depth, ponded surface area, and watershed size.

Based on remote observation and the NYSDEC database, we categorized dams in our seven study watersheds into three groups based on their ability to trap sediment and impact downstream sediment loads (Fig. 2). Group 1 impoundments are effective sediment traps, in that they presently trap greater than an estimated $10 \%$ of incoming sediment, as calculated by Brune's reservoir trap efficiency, which is based on the ratio of reservoir capacity to annual water inflow volume (Brune 1953). The estimated sediment trapping efficiency depends on sediment grain size, which is nominally fine silt. Finer-grained particles will be trapped less effectively, and coarser grain sizes will have greater retention. We approximated capacity by multiplying the average reported water depth by the ponded surface area. We estimated annual inflow as a function of watershed area and a regional average runoff value of $58 \mathrm{~cm}$ year $^{-1}$ (Gazoorian 2015), which is reasonable given the similar climate across this region. Any dam causing measurable accumulation of sediment was classified as an effective sediment trap based on the $10 \%$ threshold.

Group 2 impoundments are classified as run-of-river with limited sediment storage capacity, and have a ratio of impoundment width to river width of less than 2 . We found

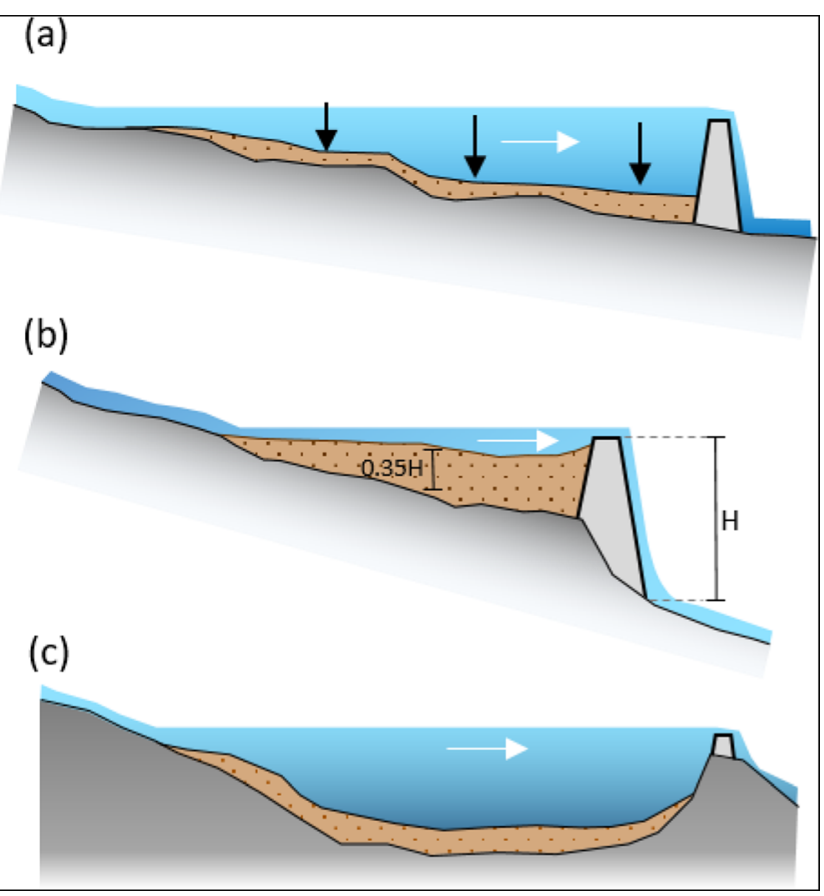

Fig. 2 Schematic representation along a transect from river inlet to dam for the three impoundment classifications, with white arrows representing direction of flow. a Schematic of an effective sediment trap (Group 1), where water depth and reservoir residence time allow for sediment trapping. Black arrows indicate representative coring locations. b Schematic of a run-of-river impoundment (Group 2), where short term deposition is balanced by scour at interannual time scales. Sediment thickness for run-of-river dams averaged $0.35 \mathrm{H}$, where $\mathrm{H}$ is the dam height. A natural knickpoint is depicted at the dam site. $\mathbf{c}$ Schematic of a dammed natural lake where sediment deposition is relatively unaffected by the presence of the dam (Group 3 )

negative values for the Brune (1953) trapping efficiency for these sites, supporting the interpretation that these dams do not trap sediment (Supplementary Table 1). Satellite photos of these impoundments revealed prominent and extensive sandy bar deposits, indicating that these dams have reached their capacity to trap sediment. Field inspection of $\sim 10$ of these sites revealed only coarse sediment in the impoundments, indicating that fine sediment trapping had ceased. Ongoing sedimentation within these impoundments is characterized by ephemeral deposition during periods of low to moderate flow and scour at high flows resulting in minimal net trapping over inter-annual time scales. Many of these Group 2 dams have been built atop natural bedrock knickpoints, with limited sediment storage as evidenced by cobble or bedrock channels upstream of the dam. Dated millpond sediments from three watersheds across the glaciated Northeast US found that many of these dams, which are small relative to their watershed areas, filled with sediment rapidly after they were constructed (Johnson et al. 2019).

Group 3 includes three types of dams that have minimal effects on watershed sediment budgets, including natural lakes with dammed outlets, breached dams, and upland spring-fed 
ponds with small watersheds, generally less than $2 \mathrm{~km}^{2}$ and without a mapped inlet stream. Natural lakes were designated when the impoundment depth exceeded the dam height, and were confirmed with publicly available bathymetric maps. These dams are generally less than $20 \%$ of the maximum lake depth and do not cause meaningful changes in sediment trapping efficiency. Their purpose is often to draw down lake stage in the winter to reduce aquatic vegetation for aesthetic purposes. Breached dams may contain legacy sediments (e.g., Walter and Merritts 2008), but we did not observe these deposits in the field. Further, after the initial pulse of sediment from dam breaching, inputs of legacy sediment quickly diminish (Dow et al. 2020; Pizzuto 2002).

A total of 17 impoundments across seven tributary watersheds were surveyed for sediment mass, accumulation rate, and grain size (Supplemental Table 1). These measurements were used to inform the sediment transport model simulations and scale up regional estimates of sediment trapping based on physiographic provinces. The surveyed impoundments represent a range of upstream watershed sizes, land cover, and underlying geology. We preferentially selected dams that were effective sediment traps (Group 1) since they play greater roles in the sediment budget, but also evaluated three runof-river dams (Group 2) that trap little sediment. At each site, a minimum of three sediment cores were collected in a transect from inlet to dam. Coring focused on the main basins that tended to have laterally continuous, fine-grained deposition. None of our study sites contained prominent coarse-grained deltas. Water depths were surveyed via canoe with an acoustic profiler. Depths were interpolated between measurements using the open source Quantum GIS (QGIS) triangular irregular network tool and the average depth of the interpolated data was multiplied by impoundment surface area to estimate water volume.

Sediment cores were analyzed for clastic and organic content. The cores were sampled every $10 \mathrm{~cm}$, and above and below visible lithologic transitions such as changes in sediment texture or color. Sample thickness was $1 \mathrm{~cm}$ and on average had a volume of $4 \mathrm{~cm}^{3}$. The change in mass during drying was recorded to estimate porosity, assuming initially saturated samples. Samples were combusted at $550{ }^{\circ} \mathrm{C}$ for $4 \mathrm{~h}$ to estimate organic fraction (Dean 1974), with the remaining mass constituting the clastic portion. After removing organics by combustion, samples were gently disaggregated by mortar and pestle and run on a Coulter laser diffraction particle size analyzer. Clastic mass was divided by initial sample volume, which was estimated using a density of 1.2 and $2.65 \mathrm{~g} \mathrm{~cm}^{-3}$ for organic and clastic material respectively (Avnimelech
Table 1 Mean discharge $\left(Q_{r}\right)$ and sediment load $\left(Q_{s}\right)$ from USGS gauges in the Hudson estuary watershed. The three estimates of sediment load are based on the (1) mean observed $Q_{s}$, (2) regression between $Q_{s}$ and $Q_{r}$ during the $Q_{s}$ observations, and (3) the regression applied to the full $Q_{r}$ time series. Discharge is averaged over the period of sediment load measurements and over the full discharge record. Letters in first column correspond to locations in Fig. 1 and data in Figs. 3 and 4.
Estimates of discharge seaward of the gauged watersheds are scaled by watershed area. The watershed below Poughkeepsie and above The Battery is assumed to have a specific sediment yield of $10 \mathrm{t} \mathrm{km}^{-2}$ year $^{-1}$ based on nearby watersheds (Yellen et al. 2014). Sediment yields are calculated based on the regression to the long-term discharge records. Tons refer to metric tons here, and throughout the paper

\begin{tabular}{|c|c|c|c|c|c|c|c|c|}
\hline & \multirow[t]{2}{*}{ USGS station } & \multirow[t]{2}{*}{$\begin{array}{l}\text { Watershed } \\
\text { area }\left(\mathrm{km}^{2}\right)\end{array}$} & \multicolumn{2}{|c|}{$\begin{array}{l}\text { Mean discharge } \\
\left(Q_{r}\right)\left[\mathrm{m}^{3} \mathrm{~s}^{-1}\right]\end{array}$} & \multicolumn{3}{|c|}{ Mean sediment load $\left(\mathrm{Q}_{\mathrm{s}}\right)\left[\mathrm{kton}_{\text {year }}{ }^{-1}\right]$} & \multirow{2}{*}{$\begin{array}{l}\text { Yield } \\
\left(\mathrm{t} \mathrm{km}^{-2} \text { year }^{-1}\right) \\
\left.Q_{r} \text { fit (all } Q_{r}\right)\end{array}$} \\
\hline & & & $Q_{s}$ obs & all $Q_{r}$ & Obs. & $Q_{r}$ fit $\left(Q_{s}\right.$ obs. $)$ & $\mathrm{Q}_{\mathrm{r}}$ fit $\left(\right.$ all $\left.\mathrm{Q}_{\mathrm{r}}\right)$ & \\
\hline $\mathrm{a}$ & Schoharie Creek (01351500) & 2295 & 29 & 32 & 131 & 124 & 300 & 131 \\
\hline $\mathrm{b}$ & Mohawk River at Cohoes $(01357500)^{*} \dagger$ & 8935 & 195 & 168 & 454 & 473 & 363 & 41 \\
\hline $\mathrm{c}$ & Upper Hudson at Waterford $(01335770)^{*}$ & 11955 & 249 & 223 & 191 & 153 & 148 & 12 \\
\hline $\mathrm{d}$ & Catskill Creek (01362090)* & 1049 & 21 & 21 & 221 & 267 & 267 & 254 \\
\hline e & Kinderhook Creek (01361000)* & 852 & 16 & 13 & 58 & 68 & 36 & 43 \\
\hline$f$ & Roeliff Jansen Kill (01362182)* & 549 & 11 & 11 & 18 & 19 & 19 & 35 \\
\hline g & Rondout Creek (01372007)* & 3069 & 65 & 64 & 106 & 87 & 87 & 28 \\
\hline $\mathrm{h}$ & Stony Clove Creek (01362370) & 80 & 2 & 3 & 14 & 16 & 155 & 1930 \\
\hline $\mathrm{i}$ & Esopus Creek at Coldbrook (01362500) & 497 & 22 & 21 & 48 & 46 & 99 & 199 \\
\hline \multirow[t]{2}{*}{$\mathrm{j}$} & Esopus Creek at Mount Marion (01364500)* & 1085 & 10 & 16 & 14 & 11 & 59 & 54 \\
\hline & Total discharging to tidal Hudson & 27494 & 567 & 516 & 1062 & 1078 & 979 & 36 \\
\hline \multicolumn{9}{|c|}{ Seaward estimates scaled by watershed area } \\
\hline & Poughkeepsie & 30406 & 627 & 571 & 1174 & 1192 & 1083 & 36 \\
\hline & The Battery & 34680 & 715 & 651 & 1217 & 1235 & 1125 & 32 \\
\hline
\end{tabular}

* Stations that discharge to the tidal Hudson and are used in total calculations

${ }^{\dagger}$ Discontinuous $Q_{s}$ coverage: 1953-1959, 1976-1979, 2004-2018 
et al. 2001) in order to determine clastic content of sediment in $\mathrm{g} \mathrm{cm}^{-3}$. Clastic content values from the centrally located sediment core in each impoundment were averaged to estimate a representative value of clastic mass per unit volume of sediment (Smith and Wilcock 2015).

Average sediment thickness for each site was based on core stratigraphy and supported by extensive probing with a $2.5 \mathrm{~cm}$ internal diameter, 5-m-long gouge corer that provided a bottom sample that could be evaluated in the field. At most sites, an abrupt increase in probing resistance signaled the transition from impoundment sediment to pre-impoundment soil or river bottom. Gouge and transparent piston-push cores provided further visual and textural evidence for this transition at all sites, including generally more organic-rich sediment above the probing resistance transition, and more cohesive and organic-depleted sediment below the transition, which was confirmed in the lab. The site-averaged sediment thickness was multiplied by impoundment area and site-averaged sediment clastic content to compute total clastic mass in each impoundment. Historical records and the NYSDEC database were used to date impoundment construction in order to calculate a rate of sediment mass accumulation. When historical records were not available, we used the $1954 \mathrm{CE}{ }^{137} \mathrm{Cs}$ onset to constrain sediment accumulation rates (Pennington et al. 1973). Mass accumulation rates were corrected for trapping efficiency and used to calculate a sediment yield estimate for the Hudson Highlands region, where there are no suitable gauge records of suspended sediment transport (see the "Discharge and Sediment Monitoring" section). In the tidal wetlands at the mouths of study watersheds, we also collected transects of cores to constrain the developmental history, accumulation rates, and sediment composition using similar methods as described above (Yellen et al. submitted).

Based on the sediment trapping characteristics of each of the three dam classes, we applied rules to scale up these observations to estimate potential for released sediment from all dams in each the study's subwatersheds. When lacking field measurements, stored sediment masses in effective sediment traps (Group 1) were estimated by using the regional sediment yield (see the "Discharge and Sediment Monitoring" section) of the upstream watershed area and the age of the dam, and adjusting downward based on the Brune (1953) trapping efficiency of the dam. We assumed a factor of $50 \%$ uncertainty in the sediment yield for field surveyed and non-surveyed impoundments based on literature (e.g., Verstraeten and Poesen 2001). For run-of-river dams (Group 2), we approximated average sediment depth as a set fraction of dam height $(\mathrm{H})$ based on our three field sites, where sediment thickness averaged $35 \%$ of listed dam height (Fig. 2). We also made field inspections of several dams that we excluded from sediment probing as they lacked any measureable fine sediment accumulation. These dams tended to be built atop natural knickpoints previously occupied by small waterfalls.
Because these dams often extend vertically from the bottom of the former waterfall to above the bedrock knickpoint, dam height at these sites can result in an over-prediction of sediment accumulation. We therefore view our aggregate estimate of sediment trapped in run-of-river dams as an upper bound, and incorporate a sediment thickness uncertainty ranging from 25 to $50 \%$ of dam height. The estimated sediment thickness was multiplied by the impoundment area and an average value of clastic mass per unit volume from the surveyed sites to convert to sediment mass. We assumed zero sediment available for release from non-source dams (Group 3), as a removal of a dam of this type would not result in any sediment being transported downstream. The aerial extent for each of the four provinces (Fig. 1c) was isolated within the study watersheds and the estimated mass of impounded sediment within each physiographic area was totaled to obtain an estimate of impounded mass per unit area. This provincial mass per unit area was then used to scale up to the total storage within each province for the entire Lower Hudson.

\section{Discharge and Sediment Monitoring}

We used daily suspended sediment discharge observations from USGS river gauging stations to characterize sediment loading to the Hudson River estuary (Fig. 1, Table 1). The two largest tributaries, the Mohawk River (Cohoes 01357500) and Upper Hudson River (Waterford 01335770), enter just upstream from the tidal limit. Gauges near the mouths of smaller tributaries that discharge into the lower Hudson include Catskill Creek (01362090), Kinderhook Creek (01361000), Roeliff Jansen Kill (01362182), and Rondout Creek (01372007). The Esopus Creek watershed includes the Ashokan Reservoir, which is the second largest reservoir in the New York City drinking water supply system (Mukundan et al. 2013). Gauges upstream of the reservoir include Stony Clove (01362370) and the Esopus at Coldbrook (01362500), and the Esopus at Mount Marion (01364500) is downstream. Rondout Creek also contains a large drinking water supply reservoir that impounds $8 \%$ of its watershed. Data from Schoharie Creek (01351500), a tributary of the Mohawk that enters just upstream of Cohoes, are also included in the analysis of watershed sediment yield because it represents a major sediment source and has physiography similar to other watersheds in the Catskills that discharge to the tidal Hudson. Discharge record lengths varied from 4 years to more than 100 years. Observed sediment discharge record lengths at most sites were brief ( $<5$ years), except for the Upper Hudson and Mohawk at Cohoes, which all had several decades of sediment observations (Fig. 3).

We used sediment-discharge rating curves to relate the observed suspended sediment discharge $\left(Q_{S}\right)$ to freshwater discharge $\left(Q_{r}\right)$. The suspended sediment measurements account for only part of the total sediment load carried by streams, 

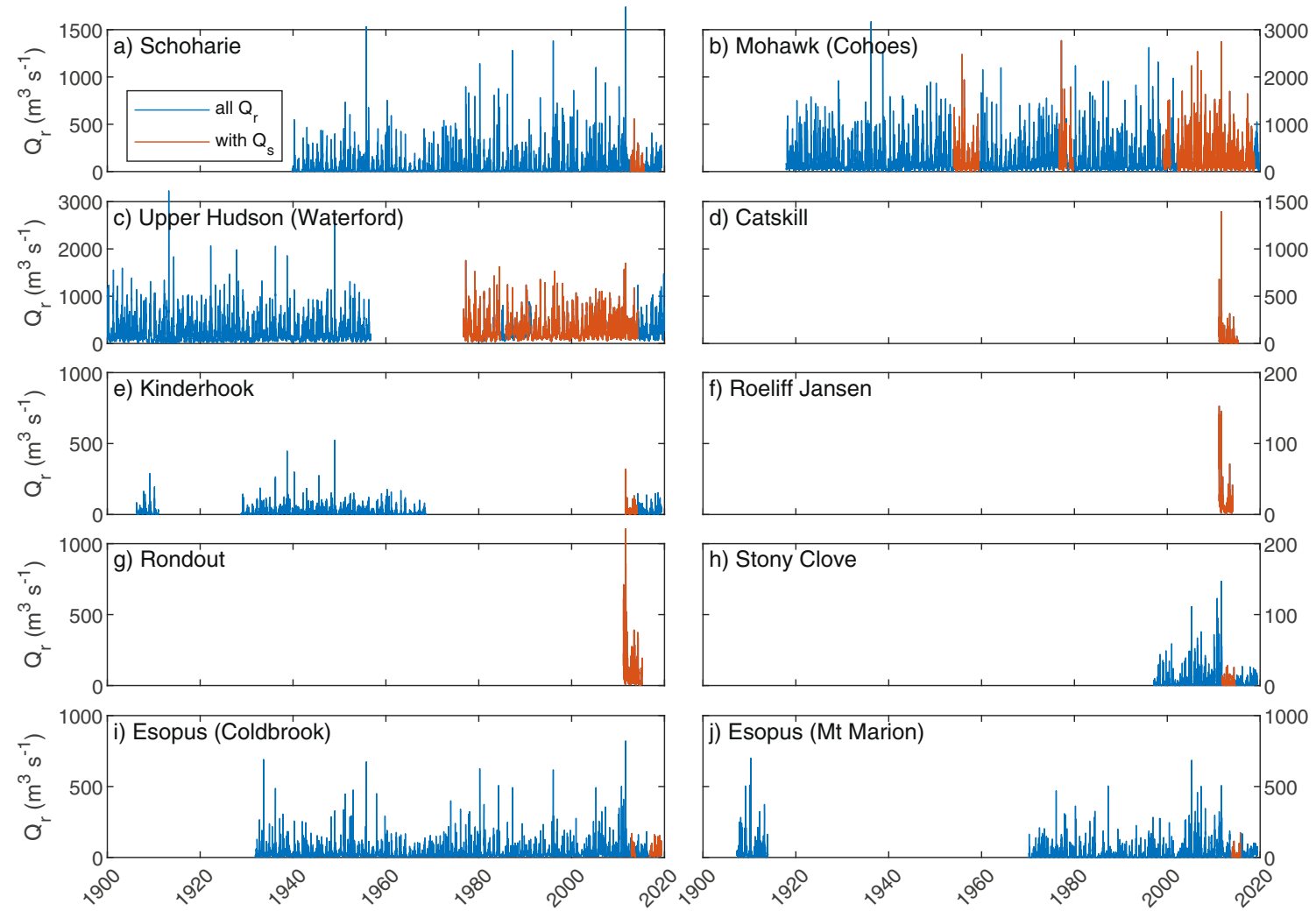

Fig. 3 Water discharge at USGS gauging stations (see Table 1 and Fig. 1). Periods highlighted in red also have sediment discharge measurements. Note the panels have different $y$-axis ranges

omitting the coarser sediment transported as bedload. However, suspended sediment is of primary interest for potential impacts on the estuary, due to its influence on water column turbidity and tidal marsh resilience (Yellen et al. submitted). The sediment-discharge rating curves use a locally weighted scatter smoothing, or LOWESS approach (Cleveland 1979; Helsel and Hirsch 2002). An alternative to a regression of $Q_{s}=a Q_{r}^{b}$ (Nash 1994), LOWESS is well suited to data where the power-law relationship between water discharge and sediment discharge is not log-linear (Hicks et al. 2000; Warrick et al. 2013). LOWESS relations between $\log _{10}\left(Q_{r}\right)$ and $\log _{10}\left(Q_{s}\right)$ were calculated for each gauging station using a smoothing factor of $f=0.2$ (Fig. 4). Similar results were found for $f=0.1$ and 0.3 . Calculated sediment discharges were computed from the regression relations and input $Q_{r}$ with a bias correction factor to account for the conversion from logtransformed variables (Cohn 1995; Ferguson 1986). The bias correction has the form $Q_{s}=10^{\wedge}\left(C_{\text {out }}+\sigma^{2} / 2\right)$, where $C_{\text {out }}$ is the output from the LOWESS regression to $\log _{10}\left(Q_{r}\right)$ and $\sigma^{2}$ is the variance in the residual of the fit. The correction resulted in an increase on the uncorrected sediment discharge for most stations by a factor between 1.1 and 1.3. Linear regressions were also calculated between $\log _{10}\left(Q_{r}\right)$ and $\log _{10}\left(Q_{s}\right)$, fitting high and low discharge regimes separately (Nash 1994; Woodruff 1999). The calculated sediment discharge using the LOWESS fits had higher correlation $\left(r^{2}=0.98\right.$, Fig. 4) than the linear regressions $\left(r^{2}=0.89\right)$, so the LOWESS fits are used for calculated sediment discharges.

\section{Sediment Transport Simulations}

A hydrodynamic and sediment transport model was used to assess the fate of sediment in the estuary from a simulated dam removal. The Coupled Ocean-Atmosphere-Wave-Sediment Transport (COAWST) modeling system (Warner et al. 2010) combines the Regional Ocean Modeling System (ROMS) (Haidvogel et al. 2008; Shchepetkin and McWilliams 2005), a free-surface, terrain-following, primitive equation ocean model that solves for 3-d velocity and salinity distributions, with the Community Sediment Transport Modeling System (Warner et al. 2008). The model implementation for the Hudson has been developed and evaluated against observations in previous studies, where additional details on model configuration, calibration, and validation can be found (Ralston et al. 2012, 2013; Ralston and Geyer 2017). The model uses the generic length scale (GLS) turbulence closure with Kantha-Clayson quasi-equilibrium stability functions, and a uniform bottom roughness of $z_{0}=0.002 \mathrm{~m}$ based on prior calibrations (Ralston et al. 2012). The grid has 16 uniformly spaced vertical layers. In the horizontal, the grid is 530 cells by 1100 cells and a resolution of 100-200 $\mathrm{m}$ in the along estuary direction and 50-100 m laterally. The grid has open 

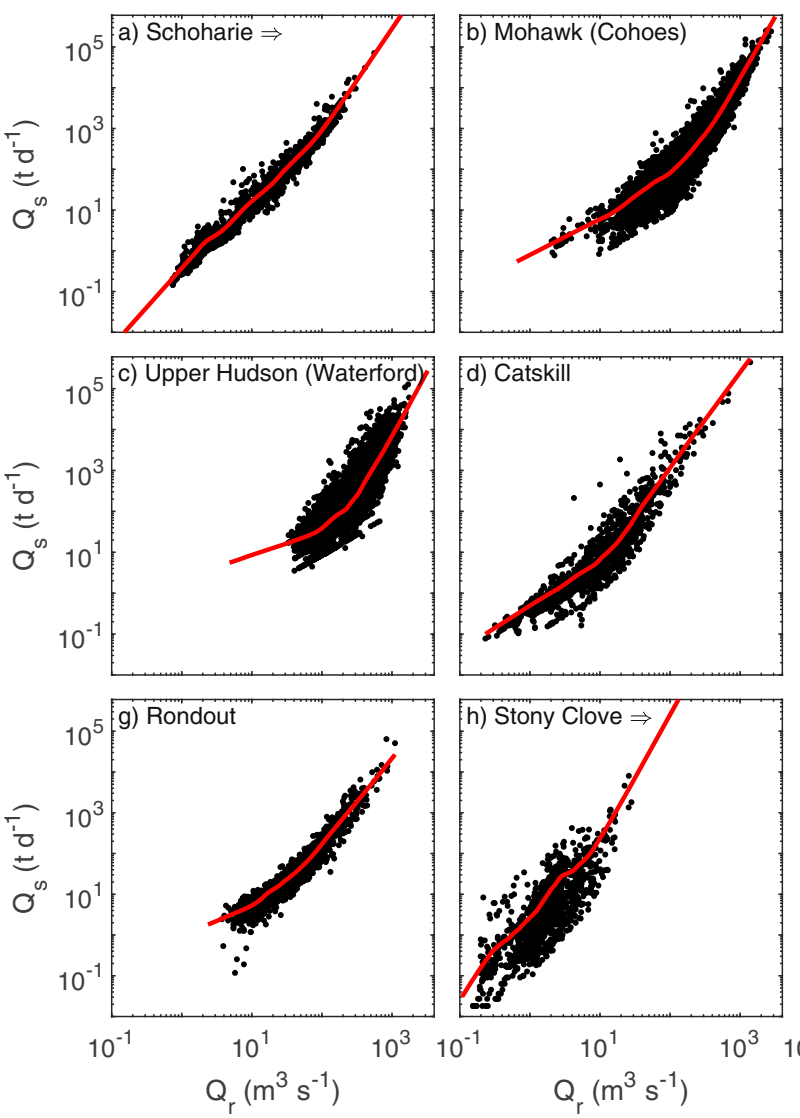

Fig. 4 Sediment discharge vs. water discharge at USGS gauging stations. Red lines are LOWESS fits, and the total calculated sediment discharge vs. observed sediment discharge for all the stations is shown in the upper

boundaries in New York Bight and Western Long Island Sound. Tidal forcing along the open boundaries is prescribed with harmonic constituents from the ADCIRC database (Mukai et al. 2002). The landward boundary in the Hudson is at the limit of tidal influence at Troy, NY. River discharges are input using data from USGS gauges for the Mohawk (01357500) and Upper Hudson (01335770) at the head of tides, and for smaller tributaries that discharge directly to the tidal Hudson: Catskill Creek (01362090), Kinderhook Creek (01361000), Roeliff Jansen Kill (01362182), Rondout Creek (01372007), and Esopus Creek (01364500). Calculated suspended sediment discharges from these rivers are from the $Q_{r}$ regressions described in the "Discharge and sediment monitoring" section.

Based on previous studies, suspended sediment transport was represented with settling velocities for seven particle size classes. The bed sediment consisted of a mixture of size classes representative of medium sand (settling velocity, $w_{s}=$ $\left.40 \mathrm{~mm} \mathrm{~s}^{-1}\right)$, fine sand $\left(w_{s}=5 \mathrm{~mm} \mathrm{~s}^{-1}\right)$, and medium-coarse silt $\left(w_{s}=0.6 \mathrm{~mm} \mathrm{~s}^{-1}\right)$. The latter size class corresponds with observed settling velocities in the saline estuary, and is likely representative of flocs (Ralston et al. 2012). Suspended
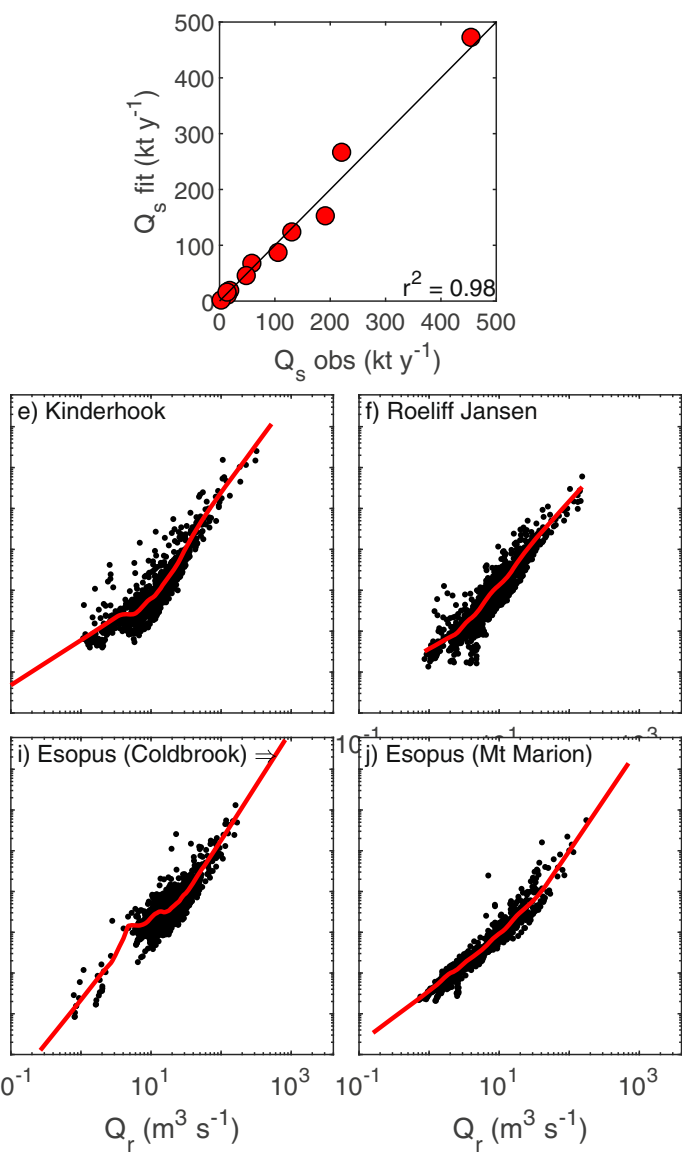

right panel. Stations located in the same subwatershed are shown adjacent to stations farther downstream and labeled with " $\rightarrow$ "

sediment input from rivers was medium silt with $w_{s}$ of $0.2 \mathrm{~mm} \mathrm{~s}^{-1}$ (Ralston et al. 2013). In the dam removal simulations, sediments were represented with three separate settling velocities of $0.02,0.2,2.0 \mathrm{~mm} \mathrm{~s}^{-1}$, nominally corresponding with fine silt $(\sim 6 \mu \mathrm{m})$, medium silt $(\sim 20 \mu \mathrm{m})$, and coarse silt $(\sim 60 \mu \mathrm{m})$. The dam removal sediment inputs were divided among three size classes based on a representative particle size distribution from impoundment cores (see "Results" section): $45 \%$ fine silt, $40 \%$ medium silt, and $15 \%$ coarse silt. The critical stress for erosion was $0.05 \mathrm{~N} \mathrm{~m}^{-2}$ and the erosion rate was $3 \times 10^{-4} \mathrm{~kg} \mathrm{~m}^{-2} \mathrm{~s}^{-1}$ for the dam removal and watershed sediment classes (Ralston et al. 2013).

To evaluate a range of forcing conditions, several seasonal time-scale periods were simulated with observed river discharge. The simulation periods were selected from previous model runs that were validated against observations of water level, velocity, salinity, and suspended sediment in the saline estuary and fresh tidal river (Ralston et al. 2013, 2012). The forcing for the dam release scenario presented here is from the spring and summer of 2014, which had a typical spring freshet followed by lower discharge conditions (Ralston and Geyer 2017). Other dam removal simulations, including high 
discharge events in 2011 and lower discharge conditions in 2015, gave qualitatively similar results, and are not presented here.

To illustrate the effects of suspended sediment inputs from a dam removal, we present results from a model scenario with increased SSC from Kinderhook Creek, which is the largest tributary in the Stockport watershed. To represent the increased sediment inputs from a dam removal in the model, the relationship between SSC and discharge for Kinderhook Creek was increased by a factor of 3 for the full simulation period. The factor of 3 increase in SSC is representative, and greater or lesser sediment inputs will result in proportional changes to the dam removal contribution to SSC in the estuary. Many factors contribute to amount and rate of sediment erosion from an impoundment, including the dam removal process, sediment grain size, impoundment geometry, and watershed slope (Foley et al. 2017; Grant and Lewis 2015; Riggsbee et al. 2007), and we do not address the range of potential scenarios here, nor do we account for fluvial transport processes between the impoundment and the estuary. Using the factor of 3 increase in SSC, the total sediment input to the estuary over a 5 -month simulation period was about 45 kt. For comparison, the largest impoundment in the watershed, Summit Lake, has a trapped sediment mass of about $120 \mathrm{kt}$ (see "Results" section). The total sediment released is representative of a moderate-to-large dam removal in the watershed, and the model provides an assessment of potential downstream impacts on the estuary. The $45 \mathrm{kt}$ of sediment input over the 5 -month simulation is also similar to the mean annual sediment input from the Kinderhook Creek watershed (see "Results" section, Table 1). In addition to the Kinderhook Creek case for the Stockport watershed, model scenarios were run representative of dam sediment inputs from the other study regions, with SSC increased by a factor of 3 from Esopus Creek for inputs near the Tivoli marshes, and from Popolopen Creek for inputs near Iona marsh.

\section{Results}

\section{Watershed Sediment Yield}

Watershed sediment yield, or mass of sediment per watershed area per time, is highly variable among catchments and with time, depending on factors such as watershed slope, geology, and land use (Syvitski et al. 2000). For example, steeper watersheds produce more sediment per unit area than low gradient regions, and intensive agriculture yields more sediment compared with forested land (Smith and Wilcock 2015). Sediment yields also depend inversely on watershed area (Milliman and Syvitski 1992). Larger watersheds have more capacity for long-term sediment storage and thus export less sediment per unit area. Here, we use monitoring data to assess the sediment discharge to the Hudson estuary and provide context for potential loading from dam removals. Most of the sediment observations in gauged tributaries are relatively recent (since 2011) and brief ( $<5$ years), and for many of the monitoring stations, the water discharge measurements span a period longer than the sediment monitoring (Fig. 3). Sediment yields are calculated based on the $Q_{s}$ vs. $Q_{r}$ regressions (Fig. 4 ) using the full $Q_{r}$ record, as well as for the period of sediment observations (Table 1).

The observed and calculated sediment yields vary inversely with watershed area (Fig. 5). Sediment yields for the largest watersheds, the Upper Hudson and Mohawk, average 16 and $51 \mathrm{t} \mathrm{km}^{-2}$ year $^{-1}$ respectively based on observed values, and are slightly lower when using long-term $Q_{r}$ regressions at 12 and $41 \mathrm{t} \mathrm{km}^{-2}$ year $^{-1}$ (Table 1). Previously reported sediment yields ranged from 8 to $27 \mathrm{t} \mathrm{km}^{-2}$ year $^{-1}$ for the Upper Hudson and 30 to $70 \mathrm{t} \mathrm{km}^{-2}$ year $^{-1}$ for the Mohawk (Wall et al. 2008). The Lower Hudson tributary watersheds draining from the west of the Hudson generally have greater sediment yields than those draining from the east (Fig. 5). For example, Catskill Creek, which drains the Catskill Mountains to the west, and Kinderhook Creek, which drains the Taconic Mountains to the east, have similar watershed areas (850 and $\left.1050 \mathrm{~km}^{2}\right)$, percent forest cover $(75 \%$ and $81 \%)$ and average basin slopes, but the sediment yields for Catskill Creek are 3 to 6 times greater due to the influence of surface geology conditions on sediment supply (Fig. 5, Table 1).

The smallest watershed with suspended sediment discharge data, Stony Clove in the Esopus Creek drainage network, has the highest estimated watershed sediment yield. The

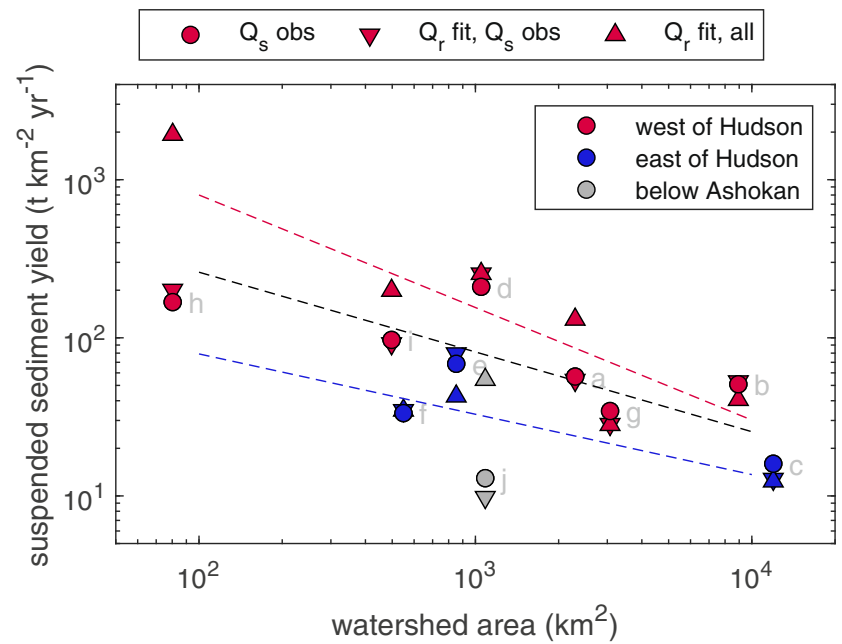

Fig. 5 Suspended sediment yield vs. watershed area. Sediment yields are calculated based on observed suspended sediment discharge, the LOWESS regression fit to $Q_{r}$ during the sediment discharge observations, and for the full $Q_{r}$ record. Stations are labeled as being west or east of the Hudson, and a station on the Esopus below the Ashokan Reservoir is noted separately. Letters correspond to the subpanels in Fig. 4. Regression lines (Eq. 1) are shown for all stations (black) and just those east (blue) or west (red) of Hudson; regression coefficients are listed in Table 2 
calculated sediment yield based on the rating curve with full discharge record (1930 t km year $\left.^{-1}, 1997-2019\right)$ is much greater than observed directly $\left(68 \mathrm{t} \mathrm{km}^{-2}\right.$ year $^{-1}$, 20112014). The sediment observations occurred during a period with few large discharge events (none greater than $30 \mathrm{~m}^{3}$ $\mathrm{s}^{-1}$ ), in stark contrast to the preceding discharge observations (27 events exceeding $30 \mathrm{~m}^{3} \mathrm{~s}^{-1}$ in the 10 years prior, Fig. $3 \mathrm{~h}$ ). Similar variability in the frequency and magnitude of discharge events over this period was observed at other locations (e.g., Schoharie Creek, Esopus Creek at Coldbrook and Mount Marion). The large difference in calculated yields for Stony Clove reflects the extreme sensitivity of sediment discharge to $Q_{r}$. Downstream on the Esopus at Coldbrook, the watershed area is greater than Stony Clove by a factor of 6 and the observed yield is lower, consistent with the overall trend with watershed area $\left(97 \mathrm{t} \mathrm{km}^{-2}\right.$ year ${ }^{-1}$ observed, $199 \mathrm{t} \mathrm{km}^{-2}$ year $^{-1}$ all discharge). Farther downstream on the Esopus at Mount Marion, the watershed area is about twice that at Coldbrook, and the calculated sediment yield decreases by a factor of 4 to 10 ( $13 \mathrm{t} \mathrm{km}^{-2}$ year ${ }^{-1}$ observed, $54 \mathrm{t} \mathrm{km}^{-2}$ year $^{-1}$ all discharge). The sharp decrease in sediment yield at the lower station is due in part to trapping by the Ashokan Reservoir, and as a result it falls below the yield-vs-area trend for other locations. By converting our core-based estimate of sediment storage in Ashokan Reservoir to sediment yield from the watershed, we find a catchment yield of approximately 90 $\mathrm{T} \mathrm{km}^{-2} \mathrm{year}^{-1}$. This is consistent with the gauge-based sediment yield estimate using observed suspended sediment concentrations from just the upstream of the reservoir at Coldbrook (Table 1).

The relation between sediment yield $(Y)$ and watershed area (A) can be represented as a power law,

$Y=c A^{d}$

where $c$ and $d$ are coefficients found by linear regression of $\log _{10}(Y)$ and $\log _{10}(A)$ (Milliman and Syvitski 1992). The sediment yields using the full $Q_{r}$ records were fit all together, as well as separately for the watersheds east and west of the Hudson to account for the differences in lithology (Fig. 5, Table 2). The resulting coefficients are comparable to those from a global assessment, which found "upland" rivers (maximum elevation 500-1000 $\mathrm{m}$ ) had $c=10^{12}$ and $d=-0.59$, and "lowland" rivers (100-500 m) had $c=10^{8}$ and $d=-0.34$ (Milliman and Syvitski 1992). The maximum watershed elevations for the study watersheds are in the range of 500-1600 $\mathrm{m}$, and the values of the exponent $d$ for the Hudson ( -0.38 to - 0.71) are similar to the global values. However, the exponents on the leading coefficient $(c)$ in the Hudson (2.7 to 4.3) are much less than the global fits, reflecting the relatively low sediment yield for the US Northeast (Meade 1969). These regressions specific to the Hudson allow estimation of the sediment yield on ungauged tributaries, and provide better
Table 2 Regression coefficients for sediment yield $\left(Y, \mathrm{t} \mathrm{km}^{-2} \mathrm{yea}^{-1}\right) \mathrm{vs}$. watershed area $\left(A, \mathrm{~km}^{2}\right)$, with the form $Y=c A^{d}$. Fits are shown for all stations and separately for the stations to the east (Taconic Mountains) and west (Catskill Mountains) of the Hudson

\begin{tabular}{llll}
\hline & $c$ & $d$ & $r^{2}$ \\
\hline All stations & $10^{3.4}$ & -.50 & 0.34 \\
East of Hudson & $10^{2.7}$ & -.38 & 0.92 \\
West of Hudson & $10^{4.3}$ & -.71 & 0.64 \\
\hline
\end{tabular}

context for the background sediment discharge in assessing potential impacts of dam removals.

Gauged rivers discharging into the tidal Hudson represent about $80 \%$ of the total watershed area, allowing for direct calculation of most of the sediment input to the estuary (Table 1). For these gauged tributaries, the total sediment discharge averaged about $1.1 \mathrm{Mt}^{\text {year }}{ }^{-1}$, based on the observed sediment discharge records or calculated from the discharge regressions. Note that for subwatersheds that have multiple gauges, this calculation uses only the lowest gauge. The total calculated sediment discharge using the regression and the full water discharge record is slightly lower than the other estimates at $1.0 \mathrm{Mt}$ year $^{-1}$, in large part because the historical discharges from the Mohawk and Upper Hudson were lower than the recent period when most of the sediment measurements were made. The more recent, higher sediment discharge periods are relevant to present conditions, and they are consistent with observations that the region is getting wetter (Armstrong et al. 2014) and yielding more sediment (Cook et al. 2015). We use watershed areas to proportionally account for ungauged watersheds, and the annual average sediment discharge to the fresh tidal river above Poughkeepsie (rkm 112) becomes $1.2 \mathrm{Mt}$ year $^{-1}$. Sediment input seaward of that is minimal due to the small watershed area and low sediment yield (described below, Table 1).

\section{Sediment Trapped in Impoundments}

Sediment mass estimates in the 17 studied impoundments ranged from 5.9 Mt in Ashokan Reservoir, built in 1915 and New York City's second largest public water supply reservoir, to $430 \mathrm{t}$ in Hand Hollow Pond, a small recreation pond built in 1980 with a contributing watershed area of $0.34 \mathrm{~km}^{2}$ drained by a perennial inlet stream (Supplemental Table 1; Yellen and Woodruff 2020). From a detailed analysis of the 97 dams in the Stockport Creek watershed (Fig. 1b), we determined that only five sites were active sediment traps (Group 1), with the remainder of the sites falling into the run-of-river (Group 2, 23 sites) and non-source (Group 3, 69 sites) categories. The total trapped sediment in the Stockport Creek watershed amounted to $0.89 \mathrm{Mt}$. The five active traps represented $0.17 \mathrm{Mt}$, of which 
roughly $70 \%$ came from one site (Summit Lake, $54 \mathrm{~km}^{2}$ watershed). Run-of-river sites contained the remainder of the sediment that could be mobilized via dam removal. Incomplete data in the NYSDEC database for small upland sites (Group 3, see methods), including missing dam ages, missing watershed sizes, and missing dam heights, make their evaluation more challenging, but the total sediment inventory at these sites is likely small, as stock and recreation ponds are commonly located along first order streams and/or receive input only from groundwater springs such that sediment inputs are minimal. For all 1700 registered dams in the Lower Hudson watershed, we found that $63 \%$ have a watershed area less than $2 \mathrm{~km}^{2}$ and $52 \%$ drain less than $1 \mathrm{~km}^{2}$, which is consistent with the fraction in the Stockport Creek watershed. While there may be some hillslope-derived sediment in these small impoundments (Nagle et al. 2007), the total drainage area of these ponds represents less than $2 \%$ of the Hudson River watershed, and therefore suggests any stored sediment is minimal. This important finding was not expected and highlights that numerous inventoried dams do not necessarily result in widespread trapping of sediment.

Impoundments in the other study watersheds were similarly categorized, and impounded sediment masses were calculated based on impoundment size characteristics from the NYSDEC database (Table 3). The Tivoli watersheds (Esopus, Saw Kill, and Stoney Creek) represent a similar total area as Stockport and have about half as many dams (52), but the impounded sediment mass is almost twice that in Stockport, about 0.65 Mt. Sediment stored in Ashokan Reservoir was not included in this value, as it is unlikely to be removed given its importance as a public water supply. The Esopus Creek watershed drains the Catskill range, which as noted above has greater sediment yield than the Taconic range east of the Hudson, where the Stockport watershed is located. The Iona watershed is smaller and has fewer dams (33), and the impounded sediment mass is a factor of 30 less than the other watersheds.

Scaling up to total impounded mass for each physiographic province based on the provincial mass/area calculated from the impoundment data, we estimate a total of $4.9 \pm 1.9 \mathrm{Mt}$ of impounded sediment for the Lower Hudson watershed, excluding storage within two large public water supply reservoirs (Table 4), Ashokan and Rondout. The impounded sediment mass in the Ashokan Reservoir, which is the largest impoundment in the Lower Hudson, is estimated to be 5.9 Mt. The $4.9 \mathrm{Mt}$ that is impounded in the numerous smaller dams in the watershed represents the potential for sediment release from dam removals, and it is about 4 times the annual average sediment input to the tidal Hudson (Table 1). The trapped mass per unit area varied considerably between physiographic provinces, likely due to historical/social and geologic influences. The Hudson Highlands had the lowest trapped mass per unit area, due in large part to the low sediment yields there. The Hudson Lowlands had the greatest mass of trapped sediment, with two large dams that are effective sediment traps (Group 1) and two run-of-river dams on large streams (Group 2) that together account for nearly half of the sediment in the 48 evaluated dams within the province. The trapped mass per unit area is similar in mountainous, rural Catskill and Taconic areas, and the slightly higher value for the Catskills is consistent with the greater sediment yields there. Across all physiographic provinces, we found that just $10 \%$ of the 182 dams that we assessed (both remotely and directly) contained $85 \%$ of the trapped sediment.

We also compare the total trapped sediment in each of the study watersheds to the calculated sediment discharge from stream gauges (Table 3). Typical watershed sediment yields were determined for Stockport $\left(60 \mathrm{t} \mathrm{km}^{-2}\right.$ year $\left.^{-1}\right)$ and Tivoli $\left(100 \mathrm{t} \mathrm{km}^{-2}\right.$ year $^{-1}$ ) (Table 3, Fig. 5), but no sediment discharge measurements were available for the Iona watershed. However, two of the Iona impoundment sites (Nawahunta and Cortlandt) are efficient sediment traps, with Brune (1953) estimates of $58 \%$ and $71 \%$ of incoming sediment trapped. Based on the age of the dams, the sediment mass accumulation since construction, and accounting for sediment that flowed through the impoundments without being trapped, we calculate sediment yields for these upstream watersheds of 6 and $11 \mathrm{t} \mathrm{km}^{2}$ year $^{-1}$. These low sediment yield estimates are consistent with
Table 3 Impounded sediment mass estimates for the three study regions. Impounded sediment masses are based on summed field observations, and impoundment categorization (trapping, run-of-river, or non-source) and physical characteristics. For comparison, watershed sediment yields are used to calculate the years of sediment supply that correspond with the impounded sediment mass

\begin{tabular}{llll}
\hline & Iona & Tivoli & Stockport \\
\hline Watershed area $\left(\mathrm{km}^{2}\right)$ & 265 & 1223 & 1340 \\
Number of dams & 33 & 52 & 95 \\
Impounded sediment mass (T) & $1.9 \mathrm{E}+$ & 4 & $5.5 \mathrm{E}+$ \\
Trapped mass uncertainty (\%) & 54 & 37 & 28 \\
Typical watershed suspended sediment yield $\left(\mathrm{t} \mathrm{km}^{-2}\right.$ year $\left.^{-1}\right)$ & 10 & 100 & 60 \\
Years of watershed supply retained & 7 & 5 & 11 \\
\hline
\end{tabular}


Table 4 Impounded sediment mass estimates by physiographic province, scaled up from the retained sediment mass per area found from the watersheds with surveyed impoundments (Table 3)

\begin{tabular}{lllllll}
\hline Physiographic province & $\begin{array}{l}\text { Impounded mass } \\
\text { per area }\left(\mathrm{t} \mathrm{km}^{-2}\right)\end{array}$ & $\begin{array}{l}\text { Total area in } \\
\text { watershed }\left(\mathrm{km}^{2} \times 10^{3}\right)\end{array}$ & Area (\%) & Mass (\%) & $\begin{array}{c}\text { Total mass }(\mathrm{Mt}) \\
\text { Mass uncertainty } \\
(\mathrm{Mt})\end{array}$ \\
\hline Hudson Highlands & 70 & 3.2 & $22 \%$ & $4 \%$ & 0.22 & 0.12 \\
Catskills & 290 & 3.1 & $22 \%$ & $18 \%$ & 0.90 & 0.33 \\
Taconics & 190 & 2.6 & $18 \%$ & $10 \%$ & 0.50 & 0.14 \\
Hudson Lowlands & 616 & 5.4 & $38 \%$ & $67 \%$ & 3.30 & 1.30 \\
Total & & & & & 4.90 & 1.90 \\
\hline
\end{tabular}

the geologic characteristics of the Hudson Highlands, where predominantly thin, rocky soils overlie erosion-resistant crystalline rock. Sediment yields from the Housatonic and Connecticut River watersheds, which are east of the lower Hudson and geologically similar, range between 8 and $30 \mathrm{t}$ $\mathrm{km}^{-2}$ year $^{-1}$ (Yellen et al. 2014). Acknowledging the uncertainty from the small number of observations, we assumed a representative value of $10 \mathrm{t} \mathrm{km}^{-2}$ year $^{-1}$ for these southern watersheds. Based on these sediment yields, the impounded sediment mass in the study watersheds represent $5-11$ years of sediment load (Table 3). Overall, the estimated $4.9 \mathrm{Mt}$ of trapped sediment corresponds with about 9 years of sediment supply from Lower Hudson tributaries. Including the sediment inputs from the Mohawk and Upper Hudson Rivers, where impounded sediment masses were not assessed, we find that the sediment trapped behind dams of the Lower Hudson represents about 4 years of average input to the estuary.

\section{Grain Size in Impoundments and Marshes}

Particle size distributions from impoundment cores were analyzed to provide information on sediment that might be mobilized following dam removals. In most impoundments, the median particle sizes $\left(d_{50}\right)$ were fine-to-medium silt, at 10-20 $\mu \mathrm{m}$ (Fig. 6). The lower ends of the distributions (represented by $d_{10}$ ) generally were clay or fine silt, whereas the upper limits $\left(d_{90}\right)$ ranged from coarse silt to medium sand. Cores were sampled at $10 \mathrm{~cm}$ intervals, but the particle size characteristics were relatively uniform with depth. Grain size varied more between impoundments than between cores in an impoundment, so only average values of $d_{10}, d_{50}$, and $d_{90}$ for each impoundment are shown. Sediment distributions from run-of-river dam sites were only slightly coarser than those from effective sediment traps (Fig. 6; Supplementary Table 1). The similarity is likely due to our sampling strategy
Fig. 6 Particle size distributions from a impoundments and $\mathbf{b}$ marshes. Markers show the average $d_{50}$, and lines show $d_{10}$ to $d_{90}$. Impoundments are grouped by subwatershed. The impoundment classification group (see the "Methods" section) is in brackets, and the number of cores at each site is in parentheses. Core data are available at https:// doi.org/10.7275/dh3v-0x33)
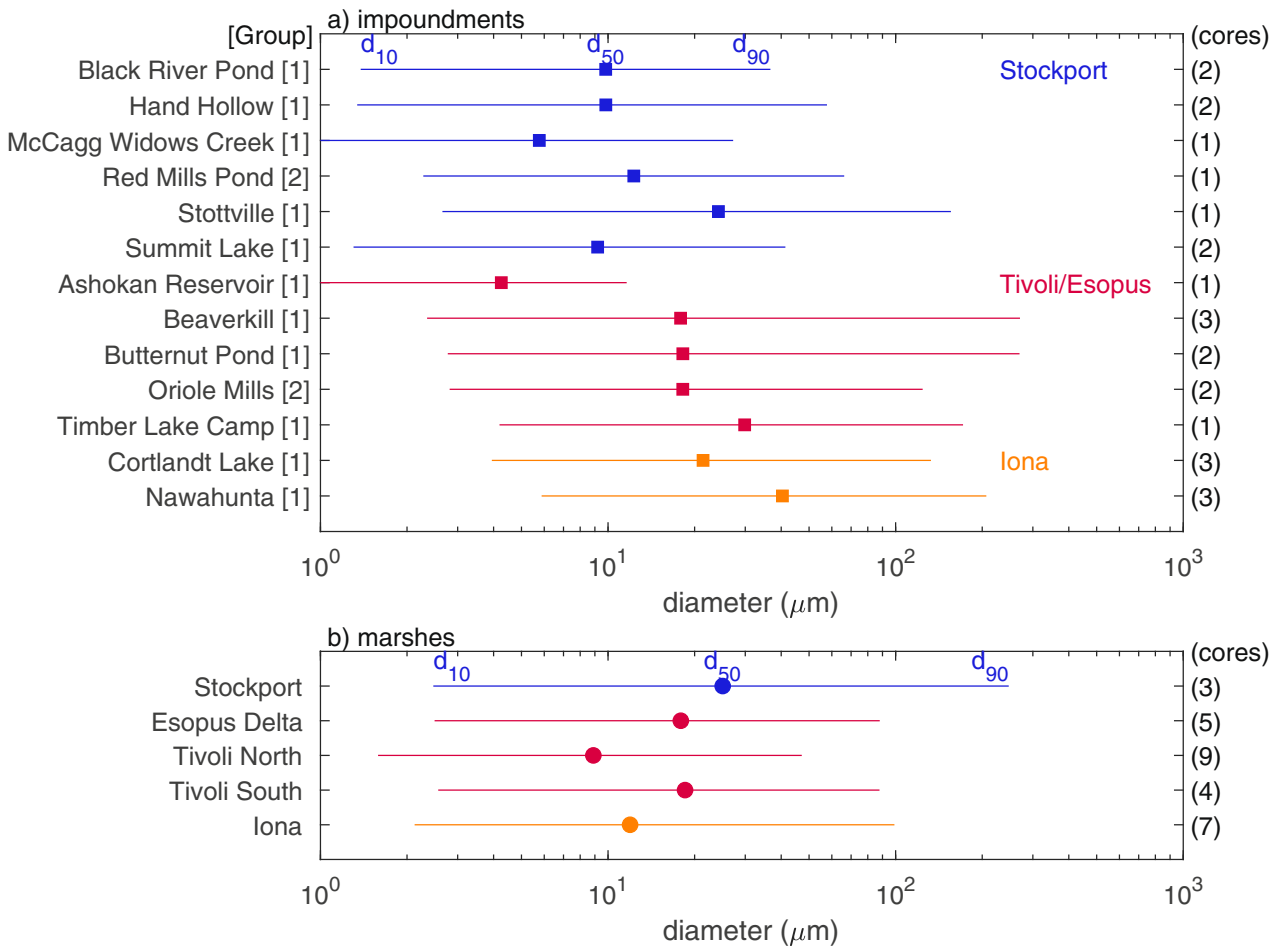
at the four run-of-river sites, where we sampled fine sediment in backwater areas or out of the main channel, and avoided cobble and gravel-mantled substrates.

The relevance of impounded sediment to wetland accretion in the estuary depends on the particle size distributions in both the source and sink regions. Cores from tidal wetlands along the Hudson were also analyzed for particle size (Fig. 6) (see also Yellen et al. submitted). Median grain size in the marsh cores ranged from 10 to $25 \mu \mathrm{m}$, and lower and upper bounds $\left(d_{10}\right.$ to $\left.d_{90}\right)$ were clay-to-fine silt $(2-4 \mu \mathrm{m})$ and very fine sand (70-100 $\mu \mathrm{m}$ ), with the $d_{90}$ potentially biased high due to incorporation of basal material. The similarities in particle size between the impoundments and marshes suggest that sediment released by dam removals could end up depositing in the marshes and contribute to accretion. However, the relevance of the impounded sediment to marsh accretion depends also on the transport pathways linking sediment from dam removals to the marshes, as well how the mass of sediment released from impoundments compares with other sediment sources to the marsh. In the next section, the numerical model is used to assess transport along the estuary of sediment from simulated dam removals from different source tributaries, including the dependence on particle size.

\section{Impacts of Simulated Dam Releases in Model Results}

Model scenarios were run with increased sediment inputs from one of the tributaries to quantify how sediment released after dam removal affects SSC and deposition in the estuary. The simulation period corresponded with spring and summer
2014. Total discharge to the estuary increased rapidly to 2500 $\mathrm{m}^{3} \mathrm{~s}^{-1}$ at the end of March and then again to $2700 \mathrm{~m}^{3} \mathrm{~s}^{-1}$ in mid-April (Fig. 7). The dam removal sediment was input from Kinderhook Creek in the Stockport watershed (rkm 188, $Q_{r \text {,avg }}=16 \mathrm{~m}^{3} \mathrm{~s}^{-1}$ ), where the first discharge event had a peak of $200 \mathrm{~m}^{3} \mathrm{~s}^{-1}$ and the second event was smaller, around $70 \mathrm{~m}^{3}$ $\mathrm{s}^{-1}$ (Fig. 7b). $Q_{s}$ depends on $Q_{r}$ (Fig. 4e) so maximum SSC in the tributary during the first discharge event was about 6 times greater than the second, and the first event had a greater impact on SSC in the estuary. For example, $13 \mathrm{~km}$ seaward of the input location, the near-bottom SSC from the dam release sediment was similar to that from all other sources, effectively doubling the near-bottom concentration (Fig. 7c), with similar increases in near-surface SSC. During the second event, and through most of the rest of the simulation period, the dam sediment concentrations were minimal compared to the total SSC at this nearest location. Brief increases in SSC due to the dam release also occurred during smaller discharge events in late spring and summer, particularly for an event in July (day 177) that had discharge of about $100 \mathrm{~m}^{3} \mathrm{~s}^{-1}$ compared to the $550 \mathrm{~m}^{3} \mathrm{~s}^{-1}$ from other tributaries. SSC in the estuary due to the dam release during this summer discharge event was similar to that from other sources (resuspension and other tributaries), but the total SSC was much less than during the spring high discharge period.

Farther seaward from the source tributary, the contribution of the dam release to the total SSC was less notable. At $36 \mathrm{~km}$ seaward, dam sediment input approximately doubled the nearbottom SSC during the first discharge event, but for only several days (Fig. 7d). Farther downstream $(91 \mathrm{~km}$ from the
Fig. 7 Suspended sediment concentrations in estuary from sediment release in model with forcing from spring 2014. a Water level at The Battery; $\mathbf{b}$ total discharge (blue) and discharge from Kinderhook Creek (teal), the tributary with the simulated dam removal; c near-bottom SSC at $13 \mathrm{~km}$ seaward from the tributary input, separating the dam removal inputs (red) from all other sediment; d SSC $36 \mathrm{~km}$ seaward from the dam removal input; e SSC $91 \mathrm{~km}$ from the input. Note the SSC panels have different $y$-axis ranges. River kilometer (rkm) is distance up estuary relative to The Battery

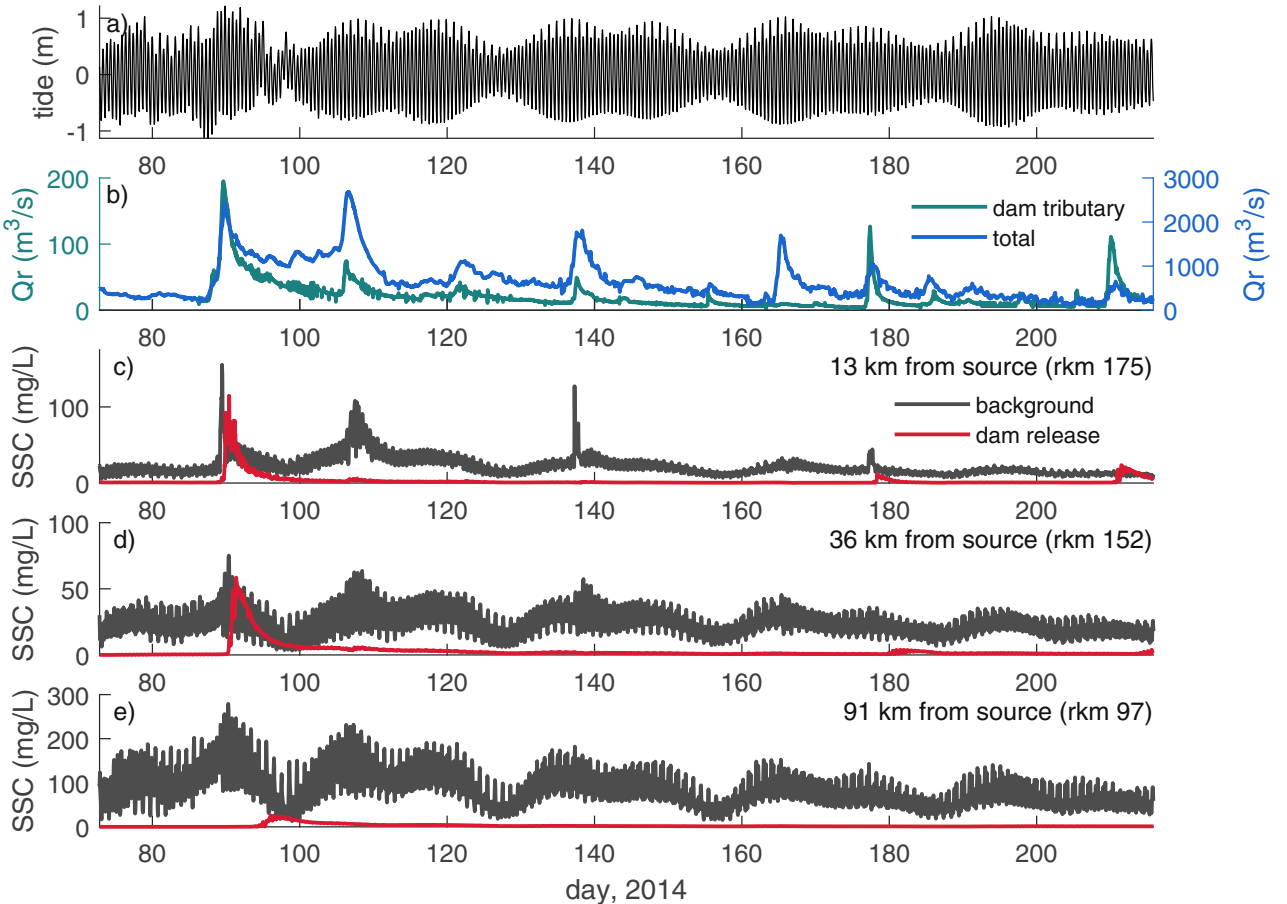


input), the simulated dam release was barely perceptible, with background tidal resuspension having a greater effect on SSC than the loading from the tributary sediment discharges (Fig. $7 \mathrm{e})$. Note that the background sediment concentrations vary among the selected locations depending on local bed composition and tidal resuspension, and the $y$-axis limits vary correspondingly. The increase in SSC from dam sediment was small compared to the background conditions with increases in SSC limited to a few days, primarily during discharge events in the local watershed. Spatially, SSC was elevated within about $10 \mathrm{~km}$ of the source tributary, or about a tidal excursion, the distance water parcels are advected over a tidal period.

In addition to SSC, sediment deposition patterns were examined in the model results. Dam release scenarios were run with increased SSC from tributaries in each of the three study regions (Stockport, Tivoli, and Iona), as detailed in the "Methods" section. Regardless of sediment input location, the particle settling velocity had a strong effect on the distance over which dam removal sediment deposited in the estuary (Fig. 8). The coarse silt fraction primarily deposited within $10-20 \mathrm{~km}$ of the input tributary. The medium silt class was transported farther seaward than the coarse silt, depositing up to $50-100 \mathrm{~km}$ from the source. The fine silt fraction deposited even more broadly and uniformly, including into the lower reaches of the estuary. The along-estuary structure of the deposition varied among the three input locations due to local differences in bathymetry, and because seaward transport rates decrease in the wider, lower reaches of the estuary, but the along-estuary deposition depended primarily on settling velocity rather than input location.

\section{Discussion}

\section{Watershed Sediment Inputs}

Total sediment discharge to the Hudson River estuary of 1.2 Mt year ${ }^{-1}$ based on the sediment-discharge regression is greater than most values that have been reported previously. Previous observations in the estuary found sediment inputs of $0.7 \mathrm{Mt} \mathrm{year}^{-1}$ above Poughkeepsie and $1.1 \mathrm{Mt} \mathrm{year}^{-1}$ above The Battery in 1959-1960 and 1977 respectively (Olsen 1979; Panuzio 1965), and watershed modeling was used to estimate 0.4-0.5 Mt year ${ }^{-1}$ to the estuary for 1984-1986 (Swaney et al. 1996), a period with lower than average discharge (Wall et al. 2008). Many estimates of sediment discharge have used short data records, or have focused on the two largest tributaries, the Upper Hudson and Mohawk. Here, we used long-term discharge and sediment data covering about $80 \%$ of the watershed area. One long-term study quantified sediment inputs over a 4-year period (2002-2006), and measured net sediment transport at Poughkeepsie (Wall et al. 2008). In that study, the annual input from the Upper Hudson and Mohawk ranged between 0.37 and $0.89 \mathrm{Mt}$, whereas seaward transport in the fresh tidal river was 0.68 to $0.83 \mathrm{Mt}$. Based on the difference between these measurements, the sediment discharge from side tributaries was estimated to be $30-40 \%$ of the total to the tidal river, or about $0.26 \mathrm{Mt}$ on average. From our stream gauge regressions, the sediment input below the tidal limit was $0.57 \mathrm{Mt}$, or about twice the previous value. The discrepancy between the two estimates may be due to sediment storage in the tidal river. Yellen et al. (submitted) estimates that $0.07 \mathrm{Mt}$ of sediment are stored annually in tidal flats and marshes along this reach, accounting for part of the difference
Fig. 8 Along-estuary deposition from sediment releases. a Coarse silt, medium silt, and fine siltsized particle deposition vs distance along estuary for the simulated dam sediment release near Stockport marsh. Black diamond marks input location, and triangles mark the advective length scales for each sediment size class calculated from Eq. 3. b Sediment deposition by size class for inputs from near Tivoli marsh, and c) near Iona Island marsh

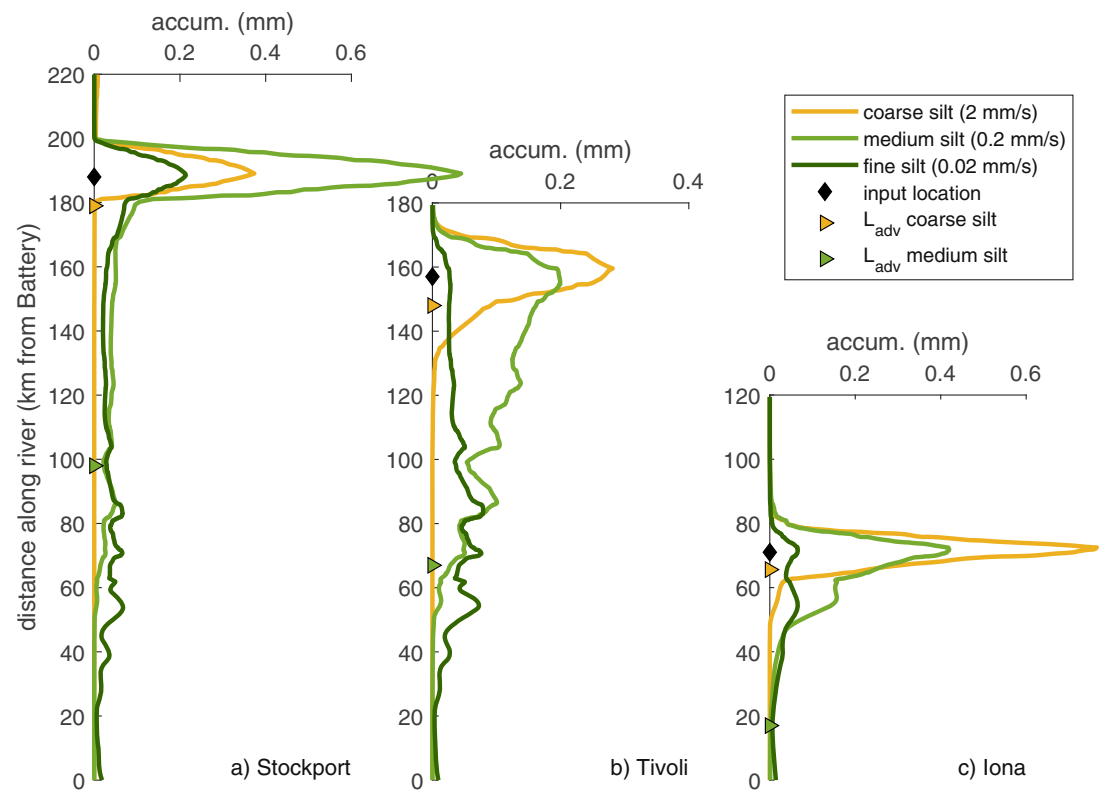


between the sediment delivery from the watershed and the transport past Poughkeepsie. Uncertainty due to discharge variability also affects both estimates. Many of the gauges in smaller watersheds were operational for just a few years that included extreme discharge events from Tropical Storms Irene and Lee in 2011. The recurrence interval for peak discharges from these events exceeded 100 years for many tributaries in the Catskill range (Lumia et al. 2014), and the total sediment input to the Hudson was about 2.7 Mt (Ralston et al. 2013). Incorporating watershed sediment loading from brief records including this period may have influenced the sediment regressions and increased sediment yields compared to the earlier study. Discharge events may also alter the particle size distribution in watershed sediment supply, which can result in errors in the sediment load estimates at stream gauges due to shifts in the relationship between turbidity and suspended mass. Sediment load uncertainty is most effectively addressed with increased water sampling at gauges over a broad range of flow conditions.

\section{Estuarine Impacts of Sediment from Dam Removals}

The increase in sediment supply due to tributary dam releases can have either negative or positive impacts on an estuary. Negative impacts include decreases in water clarity or high rates of sediment accretion that affect submerged vegetation (Glover et al. 2019; Hamberg et al. 2017) or lead to shifts in ecosystem community composition (Cloern et al. 2007; Rubin et al. 2017). On the positive side, increases in sediment supply might help tidal marshes keep up with sea level rise or reduce shoreline erosion rates (Warrick et al. 2019). The results here indicate that for dam removals in the Hudson estuary watershed, neither positive nor negative impacts are expected to be pronounced. The Hudson has relatively high background suspended sediment concentrations, from 50 to $100 \mathrm{mg} / \mathrm{L}$ in much of the fresh tidal river and higher in the saline estuary. During discharge events, direct watershed inputs can greatly increase suspended sediment concentrations, particularly in the tidal river (Ralston and Geyer 2017; Wall et al. 2008). During low to moderate flow periods in the fresh tidal river, and more generally in the saline estuary, resuspension of bed sediment by tidal currents is the dominant source of sediment in the water column.

The mobile pool of bed sediment available for resuspension can be many times greater in size than the annual sediment input from the watershed (Geyer and Ralston 2018; Schoellhamer 2011). To substantially alter the sediment mass of the mobile pool and affect turbidity in the estuary for months to years, any increase in sediment loading from dam removals would have to be many times greater than the mean annual input from the watershed, or else sustained over many years (Schoellhamer et al. 2013). The total mass of impounded sediment in the Lower Hudson is similar to about 4 years of average sediment supply. However, this total mass is not practically available for release because it is distributed in many impoundments, and given present dam removal rates, it is unlikely that many dam removals would be concurrent. Even if some of the larger dams were removed concurrently, typically only half of the impounded sediment is mobilized in a short period and some of that will be transiently stored in downstream floodplains and impoundments (Foley et al. 2017; Grant and Lewis 2015; Tullos et al. 2016). The potential impacts of impounded sediment release on the mobile pool in the estuary are small given the relatively small amount stored in impoundments and the limited number of dam removals likely to occur in short succession.

An increase in sediment loading from dam removals is analogous to the increased loading during extreme discharge events, which can deliver many times the annual average sediment input over a few days. For individual dam removals, the ratio of impounded sediment mass to annual watershed sediment load $\left(V^{*}\right)$ and the proportion of stored fines can be indicative of whether turbidity increases from dam removals will be similar to that from storm events. Dam removal sites with downstream turbidity that is substantially increased in magnitude and/or duration compared to storm events tend to be sites with $V^{*}>\sim 10$ and a high proportion of fine sediment (Major et al. 2017; Tullos et al. 2016). In the Hudson, extreme discharge events occurred in 2011 when tropical cyclones Irene and Lee resulted in sediment delivery of about $2.7 \mathrm{Mt}$ within a month (Ralston et al. 2013). Observations along the fresh tidal river and saline estuary showed increased turbidity in the months after the event. Over the longer term, turbiditydischarge relationships in the tidal river increased by 20 to $50 \%$ for up to 2 years after the events, but conditions returned to their long-term averages after that (Ralston et al. 2020). The turbidity response was coherent across multiple stations in the tidal river, but was not seen in the saline estuary, which has higher background SSC and a larger mobile sediment pool. The modest increase in turbidity from the input of $2.7 \mathrm{Mt}$ of sediment with the 2011 extreme discharge events corroborates the conclusions that release of even a large fraction of the $4.9 \pm$ 1.9 Mt of impounded sediment would also be modest, even in the unlikely scenario that it was released over a brief period. In contrast, large dams in the Western US may impound and release with dam removal sediment mass equivalent to many decades of annual input from the watershed. The Elwha is the most prominent example, where the impounded sediment mass represented about 80 years of sediment supply, and approximately $1 / 3$ of that was released downstream within 2 years by the dam removals (Warrick et al. 2015).

The increased sediment loading from dam removal could have more short-term or local impacts near source tributaries. The Hudson model results indicate that even with relatively strong tidal currents, much of the coarser fraction from a dam release deposits within a few $\mathrm{km}$ of the source, as was also the 
case for the Elwha (Gelfenbaum et al. 2015). Finer, mud-sized particles made up more than $1 / 3$ of the mass in many of the impoundments (Fig. 6), and in the model those size classes dispersed widely along the estuary. In the saline estuary, finer particles aggregate into flocs, increasing their effective settling velocity and retention (Burchard et al. 2018; Geyer et al. 2001). Sediment accumulating in wetlands consists primarily of fine particles (e.g., Fig. 6b), and these results indicate that the fine sediments from dam removals could supply marshes far from the source. However, the relatively high background SSC and marginal increases from the simulated releases indicate that effects on wetland accretion rates in the Hudson would nonetheless be small. In fact, the present sediment accumulation rates in the study marshes exceed regional rates of relative sea level rise, suggesting abundant sediment supply to the estuary even without dam removals (Yellen et al. submitted). Dam removal impacts might be more significant in an estuary with a smaller mobile sediment pool and lower background concentrations than the Hudson. For example, the Connecticut River is the adjacent major watershed to the east, and it has annual mean water and sediment discharges similar to the Hudson (Woodruff et al. 2013). However, SSC in the Connecticut estuary is much less than in the Hudson, and the bed is predominantly sand rather than mud (Patton and Horne 1992; Yellen et al. 2017). Dam removal inputs that are a significant fraction of the watershed input might have a greater impact in an estuary like this with less background sediment availability.

The strong settling velocity dependence governing the seaward transport of dam release sediment (Fig. 8) is consistent with previous observations and modeling results (Ralston and Geyer 2017). From that previous work, we can represent the seaward sediment transport along the fresh tidal river with an algebraic expression relating to channel geometry, discharge, and settling velocity. This simplified approach allows for scaling of dam removal impacts with distance from the source tributary, and it is consistent with, but independent from, the more detailed 3-d simulations. The simplified model balances sediment advection and loss to deposition, with concentration downstream from the input $C(x)$ depending on the input $C_{0}$, settling velocity $w_{s}$, water depth $H_{s}$, and an advective time scale $t_{a d v}$ due to the mean river velocity, $U_{0}=Q_{r} / A$ where $A$ is the cross-sectional area:

$\frac{C(x)}{C_{0}}=\exp \left(-f \frac{w_{s}}{H_{s}} t_{a d v}\right)$

This is based on Eq. (4) from Ralston and Geyer (2017), where we have combined their scaling factors into the coefficient $f=1 / 10$. The advective time scale can be rewritten as a length scale $L_{a d v}=U_{0} t_{a d v}$, which is related to the seaward decrease in sediment concentration:

$L_{a d v}=-10 \ln \left(\frac{C(x)}{C_{0}}\right) \frac{U_{0} H_{s}}{w_{s}}$
The average depth of the shoals, $H_{s}$, increases from $5 \mathrm{~m}$ in the upper tidal river to $12 \mathrm{~m}$ in the saline estuary (Fig. 13 of Ralston and Geyer 2017). We calculate $L_{a d v}$ for each settling velocity and dam release location using the average river discharge $\left(\approx 600 \mathrm{~m}^{3} \mathrm{~s}^{-1}\right)$ over the simulation period for $U_{0}$. Crosssectional area also increases seaward, so the effective $U_{0}$ decreases for the downstream release locations.

Advective length scales for $C / C_{0}=0.05$ are plotted as triangles in Fig. 8, representing the distance along the estuary where $95 \%$ of a particular size class is expected to deposit. The length scale estimates are independent of the 3-d model, and yet give similar results. The advective length scales for coarse silt are about $10 \mathrm{~km}$ for the release locations in the fresh tidal river, and half that for the Iona release location where the estuary cross-section is larger and $U_{0}$ smaller. In Eq. (3), $L_{a d v}$ scales inversely with settling velocity, resulting in length scales for medium silt of $100 \mathrm{~km}$ and $50 \mathrm{~km}$ respectively from the landward and seaward input locations. Advective length scales for fine silt are greater than the length of the estuary, consistent with the 3-d model results showing transport and deposition throughout the system (Fig. 8). This simplified model is not applicable in the saline estuary, where the sediment transport and deposition also depend on density-driven circulation, but the general correspondence between the advective length scale and deposition in the 3 -d model suggests that the simplified approach can help scale the influence of sediment from dam removals in the fresh tidal river.

\section{Summary}

We used observations and modeling to characterize potential impacts of suspended sediment released from dam removals in the Hudson River estuary. Using water and sediment discharge data from 10 gauging stations, we developed suspended sediment-discharge regressions and calculated average sediment discharge for tributaries that account for about $80 \%$ of the watershed area for the Hudson River Estuary, and about $90 \%$ of the watershed discharging to the tidal river (Fig. 4). The total average input to the estuary is about $1.2 \mathrm{Mt}$, of which about $45 \%$ comes from smaller watersheds that discharge directly to the tidal river. Suspended sediment yields vary inversely with watershed area in a manner similar to global rivers (Fig. 5). Suspended sediment yields also depend on regional variations in lithology, with greater yields for watershed draining the more erodible and finer textured soils of the Catskill Mountains to the west of the Hudson than those with sandier soils in the Taconic Mountains to the east. The regressions allow for estimation of sediment yield for ungauged subwatersheds of the estuary, and provide context for potential impacts of sediment released by a dam removal. 
Geophysical surveys of 17 representative impoundments and remote assessments of remaining impoundments in seven subwatersheds were used to evaluate the mass and composition of sediment retained behind roughly 1700 dams in the Lower Hudson watershed. The surveyed impoundments were grouped into three functional categories: (1) active sediment traps, (2) run-of-river sites that are no longer trapping, and (3) dams on natural lakes or springs that do not significantly alter sediment delivery. A large majority of dams in the Lower Hudson are assessed as the latter two categories and are not currently increasing sediment trapping in the watershed. For example, almost $2 / 3$ of the 1700 dams have a watershed area less than $2 \mathrm{~km}^{2}$ and about half drain less than $1 \mathrm{~km}^{2}$, which highlights that numerous inventoried dams do not necessarily result in widespread trapping of sediment. Conversely, the top $10 \%$ of dams contained $85 \%$ of impounded sediment mass, suggesting that a small number of targeted dam removals may offer the potential for sediment source restoration in sediment starved estuaries. Impounded sediment mass was calculated from cores and probing at the study sites, and these results along with a dam database were used to estimate a total impounded sediment mass of $4.9 \pm 1.9 \mathrm{Mt}$ in the Lower Hudson watershed. This total mass is similar to 4 years of average watershed sediment input to the estuary. However, if we assume based broadly on other dam removal studies that approximately half of impounded sediment is released downstream, then the potential inputs from dam removals represent only about 2 years of watershed supply.

Based on model results, sediment inputs from a representative dam removal would increase suspended sediment concentrations in the estuary, but only modestly and close to the source tributary (Fig. 7). The model results were sensitive to settling velocities, which were estimated based on particle size distributions from cores collected from impoundments (Fig. 6). Coarse silt typically deposited within $10 \mathrm{~km}$ of the source, whereas medium and fine silt dispersed more broadly along the estuary. The deposition patterns from the 3-d model were consistent with estimated transport distances from a simplified 1-d approach that could be applied more broadly. Sediment cores from impoundments and from tidal wetlands had overlapping particle size distributions, suggesting the potential for sediment released by dam removals to augment accumulation in the wetlands. However, the linkage between impoundments and wetlands depends also on transport processes in the estuary and on the relative magnitude of the sediment input from impoundments. Particle size distributions from tidal wetlands were composed predominantly of the smaller size classes, and the transport modeling indicates that inputs of this mud-sized sediment would be broadly distributed along the estuary rather than restricted to regions near the source tributaries. However, the modest mass of impounded sediment compared with the watershed sediment discharge suggests that the effects of sediment release from dam removal on the Hudson, positive or negative, would be small. Currently, sediment accretion rates in wetlands along the tidal Hudson are similar to or greater than sea level rise, indicating abundant sediment supply even with dams in place. Estuaries with lower sediment availability, or larger impoundments of fine sediment, could be affected more substantially by sediment inputs from dam removals.

Supplementary Information The online version contains supplementary material available at https://doi.org/10.1007/s12237-020-00873-3.

Acknowledgments This work was sponsored by the National Estuarine Research Reserve System Science Collaborative, which is funded by the National Oceanic and Atmospheric Administration and managed by the University of Michigan Water Center (NAI4NOS4190145). Additional support for participating graduate and undergraduates was provided by the Northeast Climate and Adaptation Center and the Hudson River Fund. Additional support for DKR was provided by the Hudson River Foundation (Grant No. 003/19A). Data from sediment cores that were collected in association with this manuscript are archived here: $\mathrm{https}: / / \mathrm{doi}$. org/10.7275/dh3v-0x33. We thank Mathias Collins and an anonymous reviewer for thoughtful feedback that greatly improved the manuscript.

Open Access This article is licensed under a Creative Commons Attribution 4.0 International License, which permits use, sharing, adaptation, distribution and reproduction in any medium or format, as long as you give appropriate credit to the original author(s) and the source, provide a link to the Creative Commons licence, and indicate if changes were made. The images or other third party material in this article are included in the article's Creative Commons licence, unless indicated otherwise in a credit line to the material. If material is not included in the article's Creative Commons licence and your intended use is not permitted by statutory regulation or exceeds the permitted use, you will need to obtain permission directly from the copyright holder. To view a copy of this licence, visit http://creativecommons.org/licenses/by/4.0/.

\section{References}

Ahearn, D.S., and R.A. Dahlgren. 2005. Sediment and nutrient dynamics following a low-head dam removal at Murphy Creek, California. Limnology and Oceanography 50 (6): 1752-1762.

Armstrong, W.H., M.J. Collins, and N.P. Snyder. 2014. Hydroclimatic flood trends in the northeastern United States and linkages with large-scale atmospheric circulation patterns. Hydrological Sciences Journal 59 (9): 1636-1655.

Ashley, J.T.F., K. Bushaw-Newton, M. Wilhelm, A. Boettner, G. Drames, and D.J. Velinsky. 2006. The effects of small dam removal on the distribution of sedimentary contaminants. Environmental Monitoring and Assessment 114 (1-3): 287-312. https://doi.org/10. 1007/s10661-006-4781-3.

Avnimelech, Y., G. Ritvo, L.E. Meijer, and M. Kochba. 2001. Water content, organic carbon and dry bulk density in flooded sediments. Aquacultural Engineering 25 (1): 25-33.

Bellmore, J.R., J.J. Duda, L.S. Craig, S.L. Greene, C.E. Torgersen, M.J. Collins, and K. Vittum. 2017. Status and trends of dam removal research in the United States. WIREs Water 4 (2): e1164. https:// doi.org/10.1002/wat2.1164.

Bowen, M.M., and W.R. Geyer. 2003. Salt transport and the timedependent salt balance of a partially stratified estuary. Journal of Geophysical Research 108 (C5): 3158. https://doi.org/10.1029/ 2001JC001231. 
Brune, G.M. 1953. Trap efficiency of reservoirs. Eos, Transactions American Geophysical Union 34 (3): 407-418.

Burchard, H., H.M. Schuttelaars, and D.K. Ralston. 2018. Sediment trapping in estuaries. Annual Review of Marine Science 10 (1): 371-395. https://doi.org/10.1146/annurev-marine-010816-060535.

Cleveland, W.S. 1979. Robust locally weighted regression and smoothing scatterplots. Journal of the American Statistical Association 74 (368): 829-836.

Cloern, J.E., A.D. Jassby, J.K. Thompson, and K.A. Hieb. 2007. A cold phase of the East Pacific triggers new phytoplankton blooms in San Francisco Bay. Proceedings of the National Academy of Sciences 104 (47): 18561-18565. https://doi.org/10.1073/pnas.0706151104.

Cohn, T.A. 1995. Recent advances in statistical methods for the estimation of sediment and nutrient transport in rivers. Reviews of Geophysics 33 (S2): 1117-1123. https://doi.org/10.1029/ 95RG00292.

Collins, M.J., N.P. Snyder, G. Boardman, W.S. Banks, M. Andrews, M.E. Baker, M. Conlon, A. Gellis, S. McClain, and A. Miller. 2017. Channel response to sediment release: insights from a paired analysis of dam removal. Earth Surface Processes and Landforms 42 (11): 1636-1651.

Collins, M.J., A.R. Kelley, and P.J. Lombard. 2020. River channel response to dam removals on the lower Penobscot River, Maine, United States. River Research and Applications n/a. 36 (9): 17781789. https://doi.org/10.1002/rra.3700.

Cook, T.L., B.C. Yellen, J.D. Woodruff, and D. Miller. 2015. Contrasting human versus climatic impacts on erosion. Geophysical Research Letters 42 (16): 6680-6687.

Dean, W.E. 1974. Determination of carbonate and organic matter in calcareous sediments and sedimentary rocks by loss on ignition; comparison with other methods. Journal of Sedimentary Research 44: 242-248.

Dicken, C.L., S.W. Nicholson, J.D. Horton, S.A. Kinney, G. Gunther, M.P. Fosse, and J.A.L. Mueller. 2005. Integrated geologic map databases for the United States: Delaware, Maryland, New York, Pennsylvania, and Virginia (Open-File Report No. 2005-1325). Reston, VA: U.S. Geological Survey.

Dow, S., N.P. Snyder, W.B. Ouimet, A.M. Martini, B. Yellen, J.D. Woodruff, R.M. Newton, D.J. Merritts, and R.C. Walter. 2020. Estimating the timescale of fluvial response to anthropogenic disturbance using two generations of dams on the South River, Massachusetts, USA. Earth Surface Processes and Landforms 45 (10): 2380-2393. https://doi.org/10.1002/esp.4886.

Doyle, M.W., E.H. Stanley, and J.M. Harbor. 2003. Channel adjustments following two dam removals in Wisconsin. Water Resources Research 39 (1). https://doi.org/10.1029/2002WR001714.

Faber, M. 2002. Natural Resources Conservation Service, in cooperation with CornellUniversity Agricultural Experiment Station. New York: Soil survey of Dutchess County.

Feng, H., J.K. Cochran, H. Lwiza, B.J. Brownawell, and D.J. Hirschberg. 1998. Distribution of heavy metal and PCB contaminants in the sediments of an urban estuary: the Hudson River. Marine Environmental Research 45 (1): 69-88.

Ferguson, R.I. 1986. River loads underestimated by rating curves. Water Resources Research 22 (1): 74-76.

Foley, M.M., J.R. Bellmore, J.E. O'Connor, J.J. Duda, A.E. East, G.E. Grant, C.W. Anderson, J.A. Bountry, M.J. Collins, P.J. Connolly, L.S. Craig, J.E. Evans, S.L. Greene, F.J. Magilligan, C.S. Magirl, J.J. Major, G.R. Pess, T.J. Randle, P.B. Shafroth, C.E. Torgersen, D. Tullos, and A.C. Wilcox. 2017. Dam removal: Listening in. Water Resources Research 53 (7): 5229-5246. https://doi.org/10.1002/ 2017WR020457.

Ganju, N.K. 2019. Marshes are the new beaches: integrating sediment transport into restoration planning. Estuaries and Coasts 42 (4): 917-926.
Ganju, N.K., N.J. Nidzieko, and M.L. Kirwan. 2013. Inferring tidal wetland stability from channel sediment fluxes: Observations and a conceptual model. Journal of Geophysical Research - Earth Surface 118 (4): 2045-2058.

Gazoorian, C.L. 2015. Estimation of Unaltered Daily Mean Streamflow at Ungaged Streams of New York, Excluding Long Island, Water Years 1961-2010. US Department of the Interior, US Geological Survey.

Gelfenbaum, G., A.W. Stevens, I. Miller, J.A. Warrick, A.S. Ogston, and E. Eidam. 2015. Large-scale dam removal on the Elwha River, Washington, USA: Coastal geomorphic change. Geomorphology 246: 649-668.

Geyer, W.R., and D.K. Ralston. 2018. A mobile pool of contaminated sediment in the Penobscot Estuary, Maine, USA. Science of the Total Environment 612: 694-707. https://doi.org/10.1016/j. scitotenv.2017.07.195.

Geyer, W.R., J.D. Woodruff, and P. Traykovski. 2001. Sediment Transport and Trapping in the Hudson River Estuary. Estuaries 24 (5): 670-679.

Glover, H.E., A.S. Ogston, I.M. Miller, E.F. Eidam, S.P. Rubin, and H.D. Berry. 2019. Impacts of suspended sediment on nearshore benthic light availability following dam removal in a small mountainous river: In Situ Observations and Statistical Modeling. Estuaries and Coasts 42 (7): 1804-1820. https://doi.org/10.1007/s12237-01900602-5.

Graf, W.L. 1999. Dam nation: A geographic census of American dams and their large-scale hydrologic impacts. Water Resources Research 35 (4): 1305-1311.

Grant, G.E., and S.L. Lewis. 2015. The remains of the dam: what have we learned from 15 years of US dam removals? In Engineering Geology for Society and Territory-Volume 3, 31-35. Cham: Springer.

Haidvogel, D.B., H. Arango, W.P. Budgell, B.D. Cornuelle, E. Curchitser, E. Di Lorenzo, K. Fennel, W.R. Geyer, A.J. Hermann, L. Lanerolle, J. Levin, J.C. McWilliams, A.J. Miller, A.M. Moore, T.M. Powell, A.F. Shchepetkin, C.R. Sherwood, R.P. Signell, J.C. Warner, and J. Wilkin. 2008. Ocean forecasting in terrain-following coordinates: formulation and skill assessment of the Regional Ocean Modeling System. Journal of Computational Physics 227 (7): 3595-3624. https://doi.org/10.1016/j.jcp.2007.06.016.

Hamberg, J., S.E.G. Findlay, K.E. Limburg, and S.A.W. Diemont. 2017. Post-storm sediment burial and herbivory of Vallisneria americana in the Hudson River estuary: mechanisms of loss and implications for restoration. Restoration Ecology 25 (4): 629-639. https://doi.org/ 10.1111/rec. 12477.

Helsel, D.R., and R.M. Hirsch. 2002. Statistical methods in water resources. Reston, VA: US Geological Survey.

Hicks, D.M., B. Gomez, and N.A. Trustrum. 2000. Erosion thresholds and suspended sediment yields, Waipaoa River basin, New Zealand. Water Resources Research 36 (4): 1129-1142.

Hoitink, A.J.F., and D.A. Jay. 2016. Tidal river dynamics: implications for deltas. Reviews of Geophysics 54: 2015RG000507. https://doi. org/10.1002/2015RG000507.

Johnson, K.M., N.P. Snyder, S. Castle, A.J. Hopkins, M. Waltner, D.J. Merritts, and R.C. Walter. 2019. Legacy sediment storage in New England river valleys: anthropogenic processes in a postglacial landscape. Geomorphology 327: 417-437. https://doi.org/10.1016/j. geomorph.2018.11.017.

Lane, E.W. 1955. Importance of fluvial morphology in hydraulic engineering. Proceedings (American Society of Civil Engineers); v. 81, paper no. 745 .

Lerczak, J.A., W.R. Geyer, and R.J. Chant. 2006. Mechanisms driving the time-dependent salt flux in a partially stratified estuary. Journal of Physical Oceanography 36 (12): 2296-2311. 
Lumia, R., G.D. Firda, and T.L. Smith. 2014. Floods of 2011 in New York: Us Geological Survey Scientific Investigations Report 20145058. https://doi.org/10.3133/sir20145058.

Magilligan, F.J., K.H. Nislow, B.E. Kynard, and A.M. Hackman. 2016. Immediate changes in stream channel geomorphology, aquatic habitat, and fish assemblages following dam removal in a small upland catchment. Geomorphology 252: 158-170.

Magirl, C.S., R.C. Hilldale, C.A. Curran, J.J. Duda, T.D. Straub, M. Domanski, and J.R. Foreman. 2015. Large-scale dam removal on the Elwha River, Washington, USA: Fluvial sediment load. Geomorphology 246: 669-686.

Major, J.J., J.E. O’Connor, C.J. Podolak, M.K. Keith, G.E. Grant, K.R. Spicer, S. Pittman, H.M. Bragg, J.R. Wallick, and D.Q. Tanner. 2012. Geomorphic response of the Sandy River, Oregon, to removal of Marmot Dam. US Department of the Interior. Washington, DC: US Geological Survey.

Major, J.J., A.E. East, J.E. O’Connor, G.E. Grant, A.C. Wilcox, C.S. Magirl, M.J. Collins, and D.D. Tullos. 2017. Geomorphic responses to dam removal in the United States-a two-decade perspective. Gravel-bed rivers 10 (9781118971437): 355-383. https://doi.org/ 10.1002/9781118971437.ch13.

McHale, M.R., and J. Siemion. 2014. Turbidity and suspended sediment in the upper Esopus Creek watershed. Ulster County, New York: US Geological Survey Scientific Investigations Report 2014-5200: 42.

Meade, R.H. 1969. Landward transport of bottom sediments in estuaries of the Atlantic Coastal Plain. Journal of Sedimentary Petrology 39: $222-234$.

Milliman, J.D., and J.P. Syvitski. 1992. Geomorphic/tectonic control of sediment discharge to the ocean: the importance of small mountainous rivers. The Journal of Geology 100 (5): 525-544.

Mukai, A.Y., Westerink, J.J., Luettich Jr, R.A., Mark, D., 2002. Eastcoast 2001, a tidal constituent database for western North Atlantic, Gulf of Mexico, and Caribbean Sea. DTIC Document.

Mukundan, R., D.C. Pierson, E.M. Schneiderman, D.M. O'donnell, S.M. Pradhanang, M.S. Zion, and A.H. Matonse. 2013. Factors affecting storm event turbidity in a New York City water supply stream. Catena 107: 80-88.

Nagle, G.N., T.J. Fahey, J.C. Ritchie, and P.B. Woodbury. 2007. Variations in sediment sources and yields in the Finger Lakes and Catskills regions of New York. Hydrological Processes: An International Journal 21 (6): 828-838.

Nash, D.B. 1994. Effective sediment-transporting discharge from magnitude-frequency analysis. Journal of Geology 102 (1): 79-96.

New York State Department of Environmental Conservation (NYSDEC). 2019. Inventory of Dams - New York State. Albany, NY: New York State Department of Environmental Conservation.

Nitsche, F.O., W.B.F. Ryan, S.M. Carbotte, R.E. Bell, A. Slagle, C. Bertinado, R. Flood, T. Kenna, and C. McHugh. 2007. Regional patterns and local variations of sediment distribution in the Hudson River Estuary. Estuarine, Coastal and Shelf Science 71 (1-2): 259-277. https://doi.org/10.1016/j.ecss.2006.07.021.

O'Connor, J.E., J.J. Duda, and G.E. Grant. 2015. 1000 dams down and counting. Science 348 (6234): 496-497. https://doi.org/10.1126/ science.aaa9204.

Olsen, C.R. 1979. Radionuclides, sedimentation and the accumulation of pollutants in the Hudson estuary (Doctoral dissertation, Columbia University)

Olsson, K.S. 1981. Soil survey of Orange County, New York (Vol. 22). US Department of Agriculture, Soil Conservation Service.

Panuzio, F.L., 1965. Lower Hudson River siltation., in: Proceedings of the 2nd Federal Interagency Sedimentation Conference, Misc. Publication. Agricultural Research Service, Jackson, MS, pp. 512550

Patton, P.C., and G.S. Horne. 1992. Response of the Connecticut River estuary to late Holocene sea level rise. Geomorphology 5 (3-5): 391-417.
Pennington, W., T.G. Tutin, R.S. Cambray, and E.M. Fisher. 1973. Observations on lake sediments using fallout $137 \mathrm{Cs}$ as a tracer. Nature 242 (5396): 324-326.

Phillips, P.J., and D.W. Hanchar. 1996. Water-quality assessment of the Hudson River Basin in New York and adjacent states. WaterResources Investigations Report 96: 4065.

Pizzuto, J. 2002. Effects of Dam Removal on River Form and Process: Although many well-established concepts of fluvial geomorphology are relevant for evaluating the effects of dam removal, geomorphologists remain unable to forecast stream channel changes caused by the removal of specific dams. BioScience 52: 683-691.

Ralston, D. K., B. Yellen, J.D. Woodruff, and S. Fernald. 2020. Turbidity hysteresis in an estuary and tidal river following an extreme discharge event. Geophys Res Letters 46: e2020GL088005, https:// doi.org/10.1029/2020GL088005.

Ralston, D.K., and W.R. Geyer. 2017. Sediment transport time scales and trapping efficiency in a tidal river. Journal of Geophysical Research - Earth Surface 122 (11): 2042-2063.

Ralston, D.K., W.R. Geyer, and J.A. Lerczak. 2008. Subtidal salinity and velocity in the Hudson River estuary: observations and modeling. Journal of Physical Oceanography 38: 753-770.

Ralston, D.K., W.R. Geyer, and J.C. Warner. 2012. Bathymetric controls on sediment transport in the Hudson River estuary: Lateral asymmetry and frontal trapping. Journal of Geophysical Research 117: C10013. https://doi.org/10.1029/2012JC008124.

Ralston, D.K., J.C. Warner, W.R. Geyer, and G.R. Wall. 2013. Sediment transport due to extreme events: The Hudson River estuary after tropical storms Irene and Lee. Geophysical Research Letters 40: 2013GL057906. https://doi.org/10.1002/2013GL057906.

Ralston, D.K., S. Talke, W.R. Geyer, H.A.M. Al-Zubaidi, and C.K. Sommerfield. 2019. Bigger tides, less flooding: effects of dredging on barotropic dynamics in a highly modified estuary. Journal of Geophysical Research, Oceans 124 (1): 196-211. https://doi.org/ 10.1029/2018JC014313.

Randle, T.J., J.A. Bountry, A. Ritchie, and K. Wille. 2015. Large-scale dam removal on the Elwha River, Washington, USA: Erosion of reservoir sediment. Geomorphology 246: 709-728. https://doi.org/ 10.1016/j.geomorph.2014.12.045.

Renwick, W.H., S.V. Smith, J.D. Bartley, and R.W. Buddemeier. 2005. The role of impoundments in the sediment budget of the conterminous United States. Geomorphology, Dams in Geomorphology 71 (1-2): 99-111. https://doi.org/10.1016/j.geomorph.2004.01.010.

Riggsbee, J.A., J.P. Julian, M.W. Doyle, and R.G. Wetzel. 2007. Suspended sediment, dissolved organic carbon, and dissolved nitrogen export during the dam removal process. Water Resources Research 43. https://doi.org/10.1029/2006WR005318.

Ritchie, A.C., J.A. Warrick, A.E. East, C.S. Magirl, A.W. Stevens, J.A. Bountry, T.J. Randle, C.A. Curran, R.C. Hilldale, J.J. Duda, G.R. Gelfenbaum, I.M. Miller, G.R. Pess, M.M. Foley, R. McCoy, and A.S. Ogston. 2018. Morphodynamic evolution following sediment release from the world's largest dam removal. Scientific Reports 8 (1): 13279. https://doi.org/10.1038/s41598-018-30817-8.

Rodriguez, A.B., B.A. McKee, C.B. Miller, M.C. Bost, and A.N. Atencio. 2020. Coastal sedimentation across North America doubled in the 20 th century despite river dams. Nature Communications 11: 1-9.

Rubin, S.P., I.M. Miller, M.M. Foley, H.D. Berry, J.J. Duda, B. Hudson, N.E. Elder, M.M. Beirne, J.A. Warrick, M.L. McHenry, A.W. Stevens, E.F. Eidam, A.S. Ogston, G. Gelfenbaum, and R. Pedersen. 2017. Increased sediment load during a large-scale dam removal changes nearshore subtidal communities. PLOS ONE 12 (12): e0187742. https://doi.org/10.1371/journal.pone.0187742.

Sawaske, S.R., and D.L. Freyberg. 2012. A comparison of past small dam removals in highly sediment-impacted systems in the U.S. Geomorphology 151-152: 50-58. https://doi.org/10.1016/j. geomorph.2012.01.013. 
Schoellhamer, D.H. 2011. Sudden clearing of estuarine waters upon crossing the threshold from transport to supply regulation of sediment transport as an erodible sediment pool is depleted: San Francisco Bay, 1999. Estuaries and Coasts 34 (5): 885-899. https://doi.org/10.1007/s12237-011-9382-x.

Schoellhamer, D.H., S.A. Wright, and J.Z. Drexler. 2013. Adjustment of the San Francisco estuary and watershed to decreasing sediment supply in the 20th century. Marine Geology 345: 63-71.

Shchepetkin, A.F., and J.C. McWilliams. 2005. The regional oceanic modeling system (ROMS): a split-explicit, free-surface, topography-following-coordinate oceanic model. Ocean Modelling 9 (4): 347-404. https://doi.org/10.1016/j.ocemod.2004.08.002.

Smith, S.M.C., and P.R. Wilcock. 2015. Upland sediment supply and its relation to watershed sediment delivery in the contemporary midAtlantic Piedmont (USA). Geomorphology 232: 33-46.

Swaney, D.P., D. Sherman, and R.W. Howarth. 1996. Modeling Water, Sediment and Organic Carbon Discharges in the Hudson-Mohawk Basin: Coupling to Terrestrial Sources. Estuaries 19 (4): 833-847. https://doi.org/10.2307/1352301.

Syvitski, J.P., M.D. Morehead, D.B. Bahr, and T. Mulder. 2000. Estimating fluvial sediment transport: The rating parameters. Water Resources Research 36 (9): 2747-2760. https://doi.org/10. 1029/2000WR900133.

Tullos, D.D., M.J. Collins, J.R. Bellmore, J.A. Bountry, P.J. Connolly, P.B. Shafroth, and A.C. Wilcox. 2016. Synthesis of Common Management Concerns Associated with Dam Removal. JAWRA Journal of the American Water Resources Association 52 (5): 1179-1206. https://doi.org/10.1111/1752-1688.12450.

Verstraeten, G., and J. Poesen. 2001. Variability of dry sediment bulk density between and within retention ponds and its impact on the calculation of sediment yields. Earth Surface Processes and Landforms 26 (4): 375-394.

Wall, G., E. Nystrom, and S. Litten. 2008. Suspended sediment transport in the freshwater reach of the Hudson River estuary in Eastern New York. Estuaries and Coasts 31 (3): 542-553. https://doi.org/10. 1007/s12237-008-9050-y.

Walter, R.C., and D.J. Merritts. 2008. Natural streams and the legacy of water-powered mills. Science 319 (5861): 299-304.

Warner, J.C., C.R. Sherwood, R.P. Signell, C.K. Harris, and H.G. Arango. 2008. Development of a three-dimensional, regional, coupled wave, current, and sediment-transport model. Computers \& Geosciences 34 (10): 1284-1306. https://doi.org/10.1016/j. cageo.2008.02.012.

Warner, J.C., B. Armstrong, R. He, and J.B. Zambon. 2010. Development of a coupled ocean-atmosphere-wave-sediment transport (COAWST) modeling system. Ocean Modelling 35 (3): 230-244. https://doi.org/10.1016/j.ocemod.2010.07.010.

Warrick, J.A., M.A. Madej, M.A. Goñi, and R.A. Wheatcroft. 2013. Trends in the suspended-sediment yields of coastal rivers of northern California, 1955-2010. Journal of Hydrology 489: 108-123.

Warrick, J.A., J.A. Bountry, A.E. East, C.S. Magirl, T.J. Randle, G. Gelfenbaum, A.C. Ritchie, G.R. Pess, V. Leung, and J.J. Duda. 2015. Large-scale dam removal on the Elwha River, Washington, USA: Source-to-sink sediment budget and synthesis. Geomorphology 246: 729-750.

Warrick, J.A., A.W. Stevens, I.M. Miller, S.R. Harrison, A.C. Ritchie, and G. Gelfenbaum. 2019. World's largest dam removal reverses coastal erosion. Scientific Reports 9 (1): 1-12. https://doi.org/10. 1038/s41598-019-50387-7.

Weston, N.B. 2014. Declining sediments and rising seas: an unfortunate convergence for tidal wetlands. Estuaries and Coasts 37: 1-23. https://doi.org/10.1007/s12237-013-9654-8.

Wilcox, A.C., J.E. O'Connor, and J.J. Major. 2014. Rapid reservoir erosion, hyperconcentrated flow, and downstream deposition triggered by breaching of $38 \mathrm{~m}$ tall Condit Dam, White Salmon River, Washington. Journal of Geophysical Research - Earth Surface 119 (6): 1376-1394. https://doi.org/10.1002/2013JF003073.

Woodruff, J.D., 1999. Sediment deposition in the lower Hudson River estuary (M.S. thesis). Massachussets Institute of Technology/Woods Hole Oceanographic Institution.

Woodruff, J.D., A.P. Martini, E.Z. Elzidani, T.J. Naughton, D.J. Kekacs, and D.G. MacDonald. 2013. Off-river waterbodies on tidal rivers: Human impact on rates of infilling and the accumulation of pollutants. Geomorphology 184: 38-50.

Yellen, B., and J.D. Woodruff. 2020. Dam impoundments sediment mass - tributaries to the Hudson River (No. 109). Data and datasets. Amherst, MA: University of Massachusetts.

Yellen, B., J.D. Woodruff, L.N. Kratz, S.B. Mabee, J. Morrison, and A.M. Martini. 2014. Source, conveyance and fate of suspended sediments following Hurricane Irene. New England, USA. Geomorphology 226: 124-134.

Yellen, B., J.D. Woodruff, D.K. Ralston, D.G. MacDonald, and D.S. Jones. 2017. Salt wedge dynamics lead to enhanced sediment trapping within side embayments in high-energy estuaries. Journal of Geophysical Research, Oceans 122 (3): 2226-2242. https://doi.org/ 10.1002/2016JC012595.

Yellen, Brian, Jonathon D. Woodruff, Caroline Ladlow, David K. Ralston, Sarah Fernald, Waverly Lau. 2020 (submitted). Rapid tidal marsh development in anthropogenic backwaters - implications for marsh creation and restoration, Geomorphology, submitted Mar 2020 . 